FIU Law Review

Fall 2008

\title{
"Latinas/os" and Latina/o Legal Studies: A Critical and Self- Critical Review of LatCrit Theory and Legal Models of Knowledge Production
}

\author{
Margaret E. Montoya \\ University of New Mexico School of Law \\ Francisco Valdes \\ University of Miami School of law
}

Follow this and additional works at: https://ecollections.law.fiu.edu/lawreview

Part of the Other Law Commons

Online ISSN: 2643-7759

\section{Recommended Citation}

Margaret E. Montoya \& Francisco Valdes, "Latinas/os" and Latina/o Legal Studies: A Critical and Self-

Critical Review of LatCrit Theory and Legal Models of Knowledge Production, 4 FIU L. Rev. 187 (2008).

DOI: https://dx.doi.org/10.25148/lawrev.4.1.17

This Symposium is brought to you for free and open access by eCollections. It has been accepted for inclusion in FIU Law Review by an authorized editor of eCollections. For more information, please contact lisdavis@fiu.edu. 


\title{
"Latinas/os" and Latina/o Legal Studies: A Critical and Self-Critical Review of LatCrit Theory and Legal Models of Knowledge Production
}

\author{
Margaret E. Montoya \\ Francisco Valdes
}

AFTERWORD

I. Introduction

A. The Promise and the Danger: "Latinas/os" as a

Demographic Surge

B. Within the Legal Academy: The Emergence of Latina/o

Legal Studies ("LatCrit")

C. Meaning and Location: The Emergence of LatCrit as a

Coalitional Antisubordination Knowledge-Production

Project

II. Knowledge Production Models: A Brief Overview

A. Imperial ("Traditional") Model ............................................201

B. Vanguardist ("Safe Space") Model ......................................214

Professor of Law, University of New Mexico School of Law and Haywood Burns Chair in Civil Rights, 2008 - 09, City University of New York.

** Professor of Law, University of Miami School of Law. As with all LatCrit knowledge production, this Afterword has benefited from a collective effort in the form of animated discussions with impassioned, if respectful, disagreements. We thank the members of the LatCrit, Inc., Board of Directors for their critical support and thoughtful encouragement. In particular we thank Board Members Steve Bender, Robert Chang, Sumi Cho, Colin Crawford, Tucker Culbertson, Berta Esperanza Hernández-Truyol, Nancy Ehrenreich, Angela Harris, Guadalupe Luna, Tayyab Mahmud, Camille Nelson, Charles Pouncy, Catherine Smith, Charles Venator Santiago, and Robert Westley for very helpful comments. We also thank Elvia Arriola, Jorge Esquirol, Laura E. Gómez, Carmen G. Gonzalez, Emily M.S. Houh, and Christine Zuni Cruz for their similarly very helpful comments and support. Finally, we thank the community of scholars represented in the various LatCrit symposia we discuss and celebrate here, without whom this body of contemporary legal discourse simply would not exist. We received invaluable assistance from Richard Cornier (Miami) and Ernesto Longa (UNM) in finalizing this Afterword. All errors stay with us.

We dedicate this Afterword to our late friend, colleague, and leader, Professor Jerome McCristal Culp, whose inspiration, insights, and spirit animate this examination of legal scholarship. We miss his encouragement, humor, and courage. 
C. Democratic ("Big Tent") Model.............................................219

III. Outsider Democracy: The LatCrit Experiment..........................231

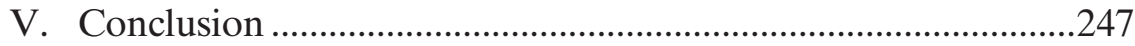

\section{INTRODUCTION}

For the twelfth time in as many years, the LatCrit community convened its annual conference to underscore the importance of location and locality in the work that we do. The conference theme's framing around Critical Localities: Epistemic Communities, Rooted Cosmopolitans and Knowledge Processes not only focused our collective attention on questions of epistemic community and intellectual (as well as physical) location, but also invited reflection on the meanings we inscribe onto the positions we elect to stake out for ourselves and our work in light of the options and traditions that serve as background. The "Critical Localities" theme invites an examination of place and space as concepts that identify where we plant, however temporarily, the epistemic communities in which we as LatCrits devote ourselves to knowledge processes. The "Critical Localities" theme also invites analysis of the effects of subordination on place and space, on geography, on land-for some they provide a sense of rootedness but for others an experience of displacement. For some the lived reality of place and space offers an identity as cosmopolitan, and for others, their relation with place and space means an imposed identity as migrante or "illegal." The theme's concepts and tropes create perches for us to explore our worlds, both near and far, as we reflect on ourselves as knowledge producers and academic activists.

With this framing, the convening of LatCrit XII serves as marker and reminder of the invention of a new, theoretical location a dozen years ago, when this ever-fluid community of activist scholars first coalesced around the LatCrit subject position. Since then, we have labored individually and collectively to construct a sense of critical location for ourselves and the work we have undertaken within both legal culture and society at large. We have striven incrementally, and not always successfully, to give meaning, content, and focus to this ongoing and still-fragile experiment in legal knowledge-production. Ever mindful of the intellectual and cultural landscapes that envelop our labors, we have aimed both to carve out a principled alternative that understands yet repudiates the unjust traditions in legal culture that stand in complicity with the neocolonial and neoliberal stratification of law and society. In mapping this ongoing effort in the context of legal knowledge-production models, this Afterword continues this labor of love. 


\section{A. The Promise and Danger: "Latinas/os" as a Demographic "Surge"}

For at least a decade now, drums have beat and trumpets blared heralding the arrival of Latinas/os onto the national policy-andpolitics stage of the United States. Pundits have declared seismic political possibilities following from this demographic "surge" while the 2000 Census confirmed that numerical growth among "Latina/o"identified populations within the lands presently known as the United States indeed continues to outpace that of other domestic social groups. ${ }^{2}$ Yet the politics of Latina/o emergence-if indeed underway-have thus far failed to register any significant changes on preexisting patterns of domination and subordination. For an example of the persistence of these patterns, one need only examine the most recent presidential election debates surrounding immigration, and particularly Latina/o immigration, which has emerged as an important domestic issue for the forces of retrenchment, regression, and exclusion in contemporary North American society. ${ }^{3}$ Latina/o politics, it seems, presents both the promise of progress and the danger of busi-

1 We are writing this Afterword while the debate about the five-year long U.S. invasion and occupation of Iraq rages on. In January 2007, George W. Bush chose the word "surge" to frame his decision to add 30,000 troops to a military effort that is widely unpopular among the U.S. public. See David S. Cloud \& Thom Shanker, Bush's Troop-Increase Plan Is Expected to Draw Six Guard Brigades to Iraq, N.Y. TIMES, Jan. 10, 2007, available at http://www.nytimes. com/2007/01/10/washington/10military.html?_r=1\&scp=3\&sq=january+10\%2C+2007+bush+spee ch\&st=nyt\&oref=slogin. We have borrowed "surge" as a frame to emphasize the dramatic public policy implications of the demographic increases in the Latina/o population. See Hispanics Rising: An Overview of the Emerging Politics of America's Hispanic Population, http://www.ndn.org/hispanic/ new-report.html (last visited Nov. 17, 2008).

2 According to the U.S. Census Bureau's data, the Hispanic (or Latina/o) population of the country has grown steadily from 9.6 million in 1970 to 35.3 million in 2000, and now is projected to expand numerically even more, to 102.6 million by 2050 . Hispanics in the United States, http://www.census.gov/population/www/socdemo/hispanic/files/Internet_Hispanic_in_US_2006. ppt\#453, 3, Slide 3.

3 As we prepare to go to press with this Afterword, the U.S. has made history by electing as President,a Barack Obama, the first African American to hold the office. (Obama is of special interest to LatCrits because he too was a law professor of color; specifically, he taught Constitutional Law, Race and the Law, and other courses for some twelve years at the University of Chicago Law School. Statement [from University of Chicago Law School] Regarding Barack Obama, http://www.law.uchicago.edu/media/index.html (last visited July 3, 2008).) To gain the presidency, Sen. Obama defeated Sen. John McCain, the nominee of the Republican Party and, during the Democratic Party primaries and caucuses, Sen. Hillary Clinton. Latina/o voters (as well as young, technologically savvy voters) were identified as key demographic groups that decided the 2008 Presidential election. Because the Republicans proposed such draconian immigration control measures as sealing the U.S./Mexico border and used such incendiary language in talking about Mexican immigrants, large numbers of Latinas/os were motivated to register and then to vote. See Hispanic Rising 2, http://www.ndn.org/hispanic/hispanics-rising2.html. Both candidates, Obama and McCain, actively sought Latina/o votes and the future political alignment of Latinos/as remains a pressing issue for both parties. See Obama and McCain Spar Over Immigration in Front of Latinos, http://blogs.abcnews.com/politicalradar/ 2008/06/obama-and-mcc-1.html (last visited July 3, 2008). 
ness-as-usual: our actions can be either another force accommodating neocolonial patterns of in/justice-or an opportunity for something different, perhaps even something better, perhaps something truly "post"-colonial in structural and substantive terms.

As we examine in this LatCrit Afterword the forces of domination and subordination within the larger United States political and social arrangements, we are focusing on the Latina/o population and its connections to the creation of cultural capital and knowledgeproduction within the legal academy. Yet, even as we envision a different future, we appreciate that our efforts build on a foundation laid by earlier generations of scholars and activists, especially the African American civil rights pioneers who toiled to establish the key sociolegal achievements of the past fifty years, such as Brown v. Board of Education and the Civil Rights statutes that dismantled the scaffolding of the vestiges of slavery and Jim Crow, and who dedicated their creativity and resourcefulness to remaking the United States into a more democratic and egalitarian society. ${ }^{4}$ Without doubt, the efforts of Latinas/os to chart a present and future unburdened by discrimination, marginalization, and exclusion have been facilitated by the work of African Americans and other groups. Without doubt, this history of interracial cooperation, coalition-building, and mutual inspiration among groups of color in the United States-however sporadic, imperfect, and temporary-has not been sufficiently excavated and disseminated. $^{5}$

Building on the work of many pioneers in legal and social movements, LatCrit scholars understand "Latinas/os" to be a multiply diverse diaspora of individuals, with commonalities and differences based on the usual categories of identity made salient in North American law and policy: race, color, class, ethnicity, national origin, immigration status, religion, gender, sexual orientation, dis/ability, ideology, and others. " Many "Latinas/os" are Hispanic, many not;

4 See generally, DERRICK BELL, RACE, RACISM AND AMERICAN LAW (Erwin Chemerinsky et al. eds., 2007); Tom Romero, War of a Much Different Kind: Poverty and the Possessive Investment in Color in the Multiracial 1960 United States, 26 CHICANO-LATINO L. REV. 69 (2006).

5 See Matsuda, infra note 69 (invoking pioneering work of Black and other civil rights activists and its relevance to our work today); see generally, RONALD TAKAKI, A DIFFERENT Mirror: A History OF Multicultural AMERICA (1993). For examples of the inter-racial coalitions that marked the struggle against school segregation, see Margaret E. Montoya, $A$ Brief History of Chicana/o School Segregation: One Rationale for Affirmative Action, 12 BERK. LA RAZA L.J. 159 (2002).

6 One example making this point, published in the annual LatCrit symposia, is Gerald P. López, Learning about Latinos, 19 CHICANO-LATINo L. REV. 363 (1998); see also Luz Guerra, LatCrit y La Des-Colonización Nuestra: Taking Colón Out, 19 CHICANO-LATINO L. REV. 351 (1998); Berta Esperanza Hernández-Truyol, Building Bridges V-Cubans without Borders: Mujeres Unidas Por Su Historia, 55 FlA. L. REV. 225 (2003); Kevin R. Johnson, “Melting Pot” or 
many Roman Catholic, many not; many use Spanish as a "native" tongue and many not. This mix is, in great part, a product of Spanish colonization, as well as a telling measure of its still-colonizing present effects. Without overlooking the salience of Spanish colonialism on the creation of "Latinas/os," we reject discursive mis/conceptions of the "Latina/o" condition in the United States today that flatten group identity into familiar but misleading stereotypes, and that additionally project neocolonial oppressions into everyday life today. ${ }^{7}$ Instead, we embrace and emphasize multidimensional understandings of Latina/o diversities that can better help to foster the consciousness of critical coalitions necessary for effective and principled social change through knowledge-production and academic activism.

In addition, the rich and messy diversities of Latinas/os in the United States (not to mention beyond) make the notion of a monolithic social group or identity difficult to conceptualize or maintain. Moreover, in our view, any permanent attempt to privilege a particular identity or social group in contemporary legal discourses would contribute very little to-and perhaps subtract quite a bit from-the coalitional knowledge-production necessary to effective antisubordination action. Thus, LatCrit programs consistently and selfconsciously have sought to rotate critical attention among various categories of law and society from year to year, or event to event. In other words, we indeed see much value in Latinas/os stepping into the center of contemporary legal discourses, in a provisional and temporary fashion, to analyze and be analyzed, to give expression to our narratives and histories, and generally to contribute to a growing body of antisubordination knowledge-and then to rotate the center to other social groups. Thus, while we would dissent from any permanent privileging of "Latinas/os" in legal scholarship generallyespecially if done so in essentialized terms-we re-affirm our LatCritical commitment to "rotating" centers of critical inquiry as a key practice of democratic knowledge-production, and approach this Afterword in this vein. ${ }^{8}$

\footnotetext{
"Ring of Fire"?: Assimilation and the Mexican-American Experience, 85 CAL. L. REV. 1259 (1997); Victor C. Romero, “Aren't You Latino?”: Building Bridges upon Common Misperceptions, 33 U.C. DAvis L. REV. 837 (2000); Gloria Sandrino-Glasser, Los Confundidos: DeConflating Latinos/as' Race and Ethnicity, 19 ChicAno-LAtino L. REV. 69 (1998); Yvonne A. Tamayo, Cubans Without Borders: Finding Home, 55 FLA. L. REV. 215 (2003).

7 See generally Francisco Valdes, Race, Ethnicity, and Hispanismo in a Triangular Perspective: The "Essential Latina/o" and LatCrit Theory, 48 UCLA L. REV. 305 (2000) (discussing Hispanismo in relationship to Latina/o identity and LatCrit theory as an antisubordination discourse).

8 The practice of rotating centers has been a key democratic practice of LatCrit theorists from the earliest days of this experiment. With this practice we seek to acquire the intellectual
} 
B. Within the Legal Academy: The Emergence of Latina/o Legal Studies ("LatCrit")

With these broad social, cultural, and intellectual developments in mind, a dozen years ago a diverse group of outsider legal scholars banded together to launch the first systematic, programmatic experiment in "Latina/o legal studies" from within the legal academy of the United States. ' Though multiply diverse across many familiar identity categories-including race, ethnicity, religion, gender, sexual orientation, intellectual agenda, geographic location, and more-this initial band of scholars denominated this effort, "LatCrit," for two reasons key to this Afterword: with this act of naming, we aimed both to highlight the enduring invisibility of Latinas/os in the national imagination and in legal culture, including outsider scholarship, and also to align ourselves substantively and methodologically with the decimated ranks of "critical" legal scholars whose work was challenging, in contemporary times, the entrenched traditions of mainstream legal culture. "LatCrit" signifies a discursive and intellectual location at

peripheral vision required to keep both locations, the core and the borders, within our analytical field of focus. See, e.g., Francisco Valdes, Afterword-Theorizing "OutCrit" Theories: Coalitional Method and Comparative Jurisprudential Experience-RaceCrits, QueerCrits and LatCrits, 53 U. Miami L. REV. 1265, 1301-04 (1999) [hereinafter Valdes, Theorizing "OutCrit” Theories].

9 LatCrit theory is an infant discourse that responds primarily to the long historical presence and general sociolegal invisibility of Latinas/os in the lands now known as the United States. As with other traditionally subordinated communities in this country, the combination of longstanding occupancy with persistent marginality fueled an increasing sense of frustration among contemporary Latina/o legal scholars, some of whom already identified with Critical Race Theory and participated in its gatherings.

Id. at 1299.

10 See generally Francisco Valdes, Foreword - Latina/o Ethnicities, Critical Race Theory, and Post-Identity Politics in Postmodern Legal Culture: From Practices to Possibilities, 9 LA RAZA L.J. 1 (1996) [hereinafter Valdes, Practices to Possibilities] (discussing the original colloquium at which the "LatCrit" subject position was first conceived); Francisco Valdes, Foreword-Poised at the Cusp: LatCrit Theory, Outsider Jurisprudence and Latina/o SelfEmpowerment, 2 HARV. LATINo L. REV. 1 (1997) (discussing the First Annual LatCrit Conference held in 1996 and the circumstances leading up to it). For current and historical information on LatCrit projects and publications, see Latina and Latino Critical Legal Theory, Inc., www.latcrit.org. For recent applications of LatCrit theory, see Margaret E. Montoya, Defending the Future Voices of Critical Race Feminism, 39 U.C. DAVIS L. REV. 1305 (2006) (arguing that cultural competence education in medical schools would benefit from LatCritical race-conscious theory and pedagogy); Margaret E. Montoya, Uniéndo Comunidades by Learning Lessons and Mobilizing Change, 27 CHICANO-LATINo L. REV. 1 (2008) (exhorting the law student members in NLLSA, the National Latino/a Law Students Association, to work more closely with LatCrit).

It bears emphasis that LatCrit theory-like outsider jurisprudence generally-emerges during times of backlash and retrenchment, including opposition to affirmative action values as well as hostility to critical studies and scholars within the legal academy. See, e.g., Richard M. Fischl, The Question that Killed Critical Legal Studies, 17 LAW \& SOC. INQUIRY 779 (1992) (discussing the backlash campaign against the Crits, and why/how it succeeded); Margaret E. Montoya, $A$ Brief History of Chicana/o School Segregation: One Rationale for Affirmative Action, 12 LA RAZA L. J. 159 (2002); Margaret E. Montoya, Of "Subtle Prejudices," White Supremacy, and 
which identity consciousness and social justice action intersect specifically to produce antisubordination knowledge that challenges in substantive and structural terms the status quo of backlash and retrenchment in and by Law. The LatCrit subject position, we think, signifies the articulation of a counter-tradition to neocolonial hegemony in North American law, policy, and society.

In this hostile environment, at this historical moment, and like other innovators in democratic knowledge-production who came before us, we "believe we can understand [critical outsider jurisprudence]-and our own careers with their implicit choices and approaches-better if we make sense of the generation[s] that preceded us." 11 With this conviction in mind, we chose to study and embrace the cumulative accomplishments of "OutCrit" legal studies" to help

Affirmative Action: A Reply to Paul Butler, 68 U. COLO. L. REV. 891 (1997) (a colloquy on applying affirmative action jurisprudence to criminalization and incarceration practices); Symposium, Countering Kulturkampf through Critique and Justice Pedagogy, 50 VILL. L. REV. 749 (2005) (publishing some of the papers presented to the Ninth Annual LatCrit Conference, focused generally on this phenomenon); Transcript, Who Gets In? The Quest for Diversity after Grutter, 52 BUFF. L. REV. 531 (2004) (proceedings from a conference examining the effects of the backlash, including the Supreme Court's Grutter decision, on law school admissions); The Future of Civil Rights: A Dialogue, Focus on LAw STUdies, VOL. XVII, No. 2, Spring 2002, at 1.

As these varied sources indicate, this academic backlash is part and parcel of the larger "culture wars" aimed at reversing New Deal and Civil Rights lawmaking legacies. Generally, culture wars and "kulturkampf" are associated with German politics, both during the Bismarckian struggle to assert secular state authority over Catholic dogma in the form of public policy, and during the efforts of the Nazi Party to reform German culture in line with their racist ideology. See generally RICHARD J. EVANS, THE COMING OF THE THIRD REICH 118-53 (2003) (focusing on the culture wars waged in Germany as part of the Nazi rise to power). This concept, however, has been used within the United States during the past couple of decades to describe campaigns aimed at reversing New Deal and Civil Rights lawmaking legacies. See, e.g., Chris Black, Buchanan Beckons Conservatives to Come "Home," Boston GloBE, Aug. 18, 1992, at A12; Paul Galloway, Divided We Stand: Today's “Cultural War” Goes Deeper than Political Slogans, CHI. TRIB., Oct. 28, 1992, at C1. These culture wars also operate to stifle criticality in general and critical approaches to legal knowledgeproduction in particular. See Francisco Valdes, Culture, "Kulturkampf," and Beyond: The Antidiscrimination Principle Under the Jurisprudence of Backlash, in THE BlACKWELl COMPANION TO LAW AND SOCIETY 271 (Austin Sarat ed., 2004) (focusing broadly on three theoretical perspectives-backlash jurisprudence, liberal legalisms, and critical outsider jurisprudence-to compare their approaches to equality law and policy in the context of backlash "kulturkampf"). Thus, the existence and persistence of LatCrit and other outsider discourses is an act of defiance against the re-imposition of neocolonial and oligarchic stratification on North American society through law.

11 Bryant Garth \& Joyce Sterling, From Legal Realism to Law and Society: Reshaping Law for the Last Stages of the Social Activist State, 32 LAW \& SOC'Y REV. 409, 410 (1998).

12 The OutCrit label is one way of expressing the commonalities shared by varied genres of contemporary legal discourses defined both by outsider positionality and critical stance. Among these we include feminist legal theory, critical race theory, critical race feminism, queer legal theory, Asian American legal theory and LatCrit theory. These overlapping and intersecting genres share a common lineage in critical legal studies and realism. See generally Francisco Valdes, Outsider Scholars, Legal Theory \& OutCrit Perspectivity: Postsubordination Vision as Jurisprudential Method, 49 DEPAUL L. REV. 831 (2000); infra Part II (on models of legal schol- 
inaugurate a new jurisprudential experiment that took those accomplishments as a point of departure both for theory (especially in the form of academic scholarship) and action (especially when directed at reforming and transforming legal culture, and especially as performed in legal academia) in critical and self-critical ways. ${ }^{13}$ As a result, though no formal or operational canon has been consecrated, LatCrit is perhaps one of the most highly self-aware and highly theorized experiments in contemporary legal discourses. ${ }^{14}$ In other words, the original choices and basic approaches we summarize below are well considered as well as fully elaborated elsewhere. ${ }^{15}$

\section{Meaning and Location: The Emergence of LatCrit as a Coali- tional, Antisubordination Knowledge-Production Experiment}

As we summarize below, these principles and practices gave rise to the LatCrit version of a "democratic" approach to critical legal

arship and LatCrit's jurisprudential links and precursors). LatCrit also allies itself with scholars working in the area of tribal and indigenous legal studies with theoretical ties to international human rights and post-colonial movements, such as the Zapatistas in Chiapas. See Christine Zuni Cruz, Shadow War Scholarship: Indigenous Legal Tradition and Modern Law in Indian Country, 47 WASHBURN L.J. 631 (2008), [hereinafter Zuni Cruz, Shadow War Scholarship].

13 "[A]lmost from the outset we have sought to develop a theory about legal theory. At our gatherings and through our early writings, we continually and critically theorize about the purpose of our theorizing." Francisco Valdes, Under Construction: LatCrit Consciousness, Community, and Theory, 85 CAL. L. REV. 1087, 1092 (1997) [hereinafter Valdes, Under Construction]. LatCrit "represents a self-conscious effort to recast legal theory as such. LatCrit theory signifies a particular consciousness about, and approach to, the work of a legal theorist." Id. at 1096.

14 Id. Self-criticality is a long-standing feature of LatCrit theorizing. See, e.g., Margaret E. Montoya, LatCrit Theory: Mapping Its Intellectual and Political Foundations and Future SelfCritical Directions, 53 U. MIAMI L. REV. 1119 (1999) (this introduction to a cluster of symposium essays contains an extended colloquy with Profs. Kevin Johnson and George Martinez about incorporating into LatCrit the anti-sexist and anti-homophobic lessons learned by Chicana/o scholars). Perhaps the best way to appreciate the collective self-awareness and self-criticality of the LatCrit community is to review the Forewords and Afterwords to the various symposia produced during the past dozen years. Those Forewords and Afterwords serve as "bookends" that aim to anchor each symposium within the larger frames of our collective, ongoing work, and thus exemplify the care with which LatCrit theorists have approached the work of critical theory as antisubordination praxis and academic activism. For a review of the twenty-some LatCrit symposia already published, see infra note 140 .

15 The operational materials attached to each of the projects described and listed on the LatCrit website are evidence of the care and attention that has gone into designing, launching, and maintaining each project. See, e.g., the Critical Global Classroom, the South-North Exchange, the Student Scholar Project, CLAVE, etcetera. Each of these projects is the result of scholarly discussions and organizational debates, and LatCrit members have taken time and effort to theorize, thematize, and create explicit linkages among the projects. See generally LatCrit Primer, Flyer, and/or Portfolio of Projects at http://www.latcrit.org/. See Valdes, Under Construction, supra note 13 (providing an early exposition of these points). 
studies, as well as to the then-incipient field of Latina/o legal studies. ${ }^{16}$ We believe the LatCrit experience in Latina/o legal studies provides many lessons to help ensure that Latina/o discourses and politics will be more liberational and pluralistic than assimilationist or neocolonialist. $^{17}$ While being no panacea, we believe this model is best suited for the articulation of "Latina/o" identity in law and society, in part because of historical legacies and structural circumstances-like other traditionally marginalized groups, Latinas/os in the United States today face an entrenched, righteous, and majoritarian status quo resistant to transformative social change. ${ }^{18}$ In addition to antisubordination ethics, and as a pragmatic bottom-line, we think that, to effectuate transformation from a position of structural disadvantage, Latinas/os must address and transcend these personal, historical, and

16 Within the more general, interdisciplinary area of ethnic studies, genres like Chicana/o Studies, Puerto Rican Studies, and Central American Studies developed and took hold, usually located within the humanities and/or social sciences. LatCrit scholars have explored the contribution of Chicana/o Studies to LatCrit legal scholarship and academic activism. E.g., Kevin R. Johnson \& George A. Martinez, Crossover Dreams: The Roots of LatCrit Theory in Chicana/o Studies Activism and Scholarship, 53 U. MiAmI L. REV. 1143 (1999); Margaret E. Montoya, LatCrit Theory: Mapping its Intellectual and Political Foundations and Future Self-Critical Directions, 53 U. MiAmi L. REV. 1119 (1999) (a colloquy with Profs. Johnson and Martinez about the anti-sexist and anti-homophobic lessons learned by Chicana/o scholars).

17 See infra notes 31-110 and accompanying text (outlining the differences in knowledgeproduction practices or models).

18 The histories of group de jure marginalization based on race, ethnicity, gender, and other axes of identity in North American society is well documented and generally known. E.g., RACE AND RACES: CASES AND RESOURCES FOR A DIVERSE AMERICA (Juan F. Perea, Richard Delgado, Angela P. Harris \& Stephanie M. Wildman eds., 1999) (providing a historical and legal overview of racial and ethnic outsiders in the United States); see also LATINOS AND THE LAW: CAses And Materials (Richard Delgado, Juan F. Perea, Jean Stefancic eds., 2008) (focusing on the Latina/o experience in the United States). For a recent acclaimed exposition of the Black experience, which continues the project of reclaiming these distorted or suppressed histories, see DAVID BRION DAVIS, INHUMAN BONDAGE: THE Rise AND FALl OF SLAVERY IN THE NEW WORLD (2006). Similarly, for a historically recent account of sex integration in its early stages at Yale Law School during the mid-late 1980s, see Catherine Weiss \& Louise Melling, The Legal Education of Twenty Women, 40 STAN. L. REV. 1299 (1987-1988). Thus, from the beginning, [t]he configuration of LatCrit interventions, both written and physical, . . has been guided by a solid conviction that the social or legal position of multiply diversified Latina/o populations may be understood best-maybe only-when approached from multiple perspectives in collaborative but critical and self-critical fashion. . . . In both structural design and substantive scope, the LatCrit approach to outsider jurisprudence is calculated to nurture cross-group communities and intergroup coalitions spurred by intersectional discussions and projects that broaden, deepen and contextualize self-empowerment quests both within and beyond "Latina/o" contexts . . . This expansive approach to the articulation of LatCrit theory is designed to ensure that African American, Asian American, Native American, feminist, Queer and other OutCrit subjectivities are brought to bear on Latinas/os' places and prospects under the Anglocentric and heteropatriarchal rule of the United States. Valdes, supra note 8, at 1302. 
structural realities. ${ }^{19}$ To change the facts on the ground, we must deal with questions of history, power, and possibility.

This engagement, therefore, calls for more than single-issue nationalisms that, among disempowered minorities, can never hope to garner enough traction to make a serious and enduring dent in established patterns of domination and subordination. ${ }^{20}$ In the context of the United States, this engagement, to be successful, requires capacious, coalitional projects capable of overcoming entrenched and majoritarian obstacles to social justice. ${ }^{21}$ These coalitional projects, however, cannot be grounded merely in the ephemeral kinds of "converging interests" that help to explain the Civil Rights successes of the mid-twentieth century, and that two decades later helped to seal their limited fates. As history (and the work of critical outsider pioneers) has taught us, interest convergence provides, at best, a temporary and thin platform for concerted social justice action. ${ }^{22}$ Thus, rather than

19 LatCrits should be proactive about nurturing a self-critical evolution of our collective endeavors precisely because the lessons of comparative jurisprudential experience are not limited to our immediate condition. On the contrary, comparative experience can provide lessons applicable to the larger set or intra- and inter-group issues that afflict these times. From the lessons of our comparative experiences LatCrit and allied scholars can and must extrapolate both inward and outward advances: inwardly, we must develop critical antisubordination coalitions through our collective jurisprudential experiments with knowledge and community and, outwardly, we must link the lessons of comparative experience to the current positions and strategies of the larger communities from which we hale [sic]. It would be foolish, after all, to imagine that the professorate of color in the legal academy is unique in our relationship to the intra- and inter-group experiences, issues, and aspirations that pervade our communities and this society. Id. at 1269 n. 15 .

20 This approach consciously is designed to center not only Latinas/os and our many diversities in a manner that minimizes privileging any one Latina/o interest over another, but also to ensure critical discussion of Latinas/os as part of the larger social schematics formed in part through law. This LatCrit drive for diversity and particularity ideally will help to create an intellectual and social culture enabling the LatCrit community collectively to overcome Latina/o and other essentialisms, which sometimes stand in the way of critical outgroup and OutCrit coalitions. This incremental critical effort is intended to promote and ground intra and intergroup antisubordination coalitions by ensuring the representation and investigation within the LatCrit community of various power hierarchies and their interplay. Id. at 1303.

21 Through comprehensive examinations of bigotry and domination, LatCrit projects can help to locate the appropriate sites of coalitional cooperation, thereby deepening the law's commitment to reform on multiple fronts of oppression and broadening Latina/o resistance to the politics of backlash and retrenchment. Furthermore, by appreciating how varied species of discrimination become systems of subordination, which then operate as inter-linked networks of oppression, all genres and subject positions of critical legal scholarship can contribute to a capacious anti-subordination project. Only this sort of mutual, collaborative project, based on a clear vision of inter-connected group/power relations, can counter the pervasive and insidious crosslinkages of racism, nativism, androsexism, heterosexism, and classism in law and in society. Valdes, Practices to Possibilities, supra note 10, at 29.

22 See Derrick A. Bell, Jr., Brown v. Board of Education and the Interest-Convergence Dilemma, 93 HARV. L. REV. 518 (1980) (observing that Civil Rights progress depended on a perceived convergence of interests between majority and minority interests). This notion was corroborated in chilling detail years later, when secret government documents revealed that 
settle now for still more rickety coalitions based on the short-term politics of self interest, we emphasize the utility of a principled alternative based on post-subordination vision, an alternative explored and modeled (even if imperfectly) in the LatCrit context during the past decade or more.

In our view, the principal purpose of Latina/o legal studies must be to elucidate and disseminate suppressed knowledge that can help to facilitate this sort of social justice action. ${ }^{23}$ From our perspective, the point of situating Latinas/os at the center of contemporary legal discourses must be to nudge along this inter-generational, international, and interdisciplinary struggle against historic supremacies and present hierarchies. $^{24}$ As a matter both of pragmatism and principle,

federal civil rights efforts were motivated in part by Cold War competition for the hearts and minds of the "Third World"-comprised mostly of people of color. See MARY L. DUDZIAK, COld WAR Civil Rights: RACE AND THE IMAGE OF AMERICAN DEMOCRACY (2000); Mary L. Dudziak, Brown as a Cold War Case, 91 J. AM. Hist. 32 (2004). Contemporary scholars continue to explore how interest convergence explains the ebbs and flows of social justice progress. See, e.g., Cynthia Lee, Cultural Convergence: Interest Convergence Theory Meets the Cultural Defense, 49 ARIZ. L. REV. 911 (2007) (exploring identity-inflected issues in criminal law contexts).

23 Elucidating and disseminating suppressed knowledge is of particular urgency given the concentration of Latinas/os and other students of color in schools that are overwhelmingly segregated. The Pew Hispanic Center reports that in 2005-06 three in ten Hispanic and Black students were attending all-minority schools (where less than $5 \%$ of the students are white) and this trend has been growing rather than abating. See Rick Fry, The Changing Racial and Ethnic Composition of U.S. Schools, http://pewhispanic.org/reports/report.php?ReportID=79. The Tucson Unified School District, to cite an illustrative example, responded to its highly diverse student population by creating ethnic studies programs in certain high schools, which incorporated both Critical Race Theory and LatCrit scholarship. Dr. Augustin Romero, the director of the ethnic studies program, reported significant improvements in the academic performance in the cohort of students who took the ethnic studies courses. For instance, the students' performance on the local standardized test, the Arizona Instrument to Measure Standards, improved (as much as $23 \%$ in reading, writing and math) in comparison to a cohort of students who were not enrolled in ethnic studies. See Augustine Romero, Towards A Critically Compassionate Intellectualism Model of Transformative Education: Love, Hope, Identity, and Organic Intellectualism Through the Convergence of Critical Race Theory, Critical Pedagogy, and Authentic Caring (unpublished Ph.D dissertation defended April 3, 2008, University of Arizona, Graduate College) (on file with authors) (Chapter 10). The lack of official support garnered by this program illustrates the phenomenon of backlash and cultural warfare in this context. See supra note10 and sources cited therein (on cultural warfare, backlash politics, and retrenchment in law and policy). Conservative forces, including the Superintendent of Schools Tom Horne, have repeatedly challenged these programs as racist, divisive, and un-American while failing to acknowledge their effectiveness in improving retention and academic performance for largely forgotten, and effectively ignored and underserved, Latina/o students. See http://www.tucsoncitizen.com/ss/ fromcomments/88086.php (last visited 6/23/08).

24 We take as a starting point that higher education, especially legal education, produces a cadre of workers who have traditionally serviced the perpetuation of unjust enrichment in the form of corporate power and ancestral fortunes amassed during periods of de jure subordination. The starting salaries and the social prestige enjoyed by new lawyers, even though they are made to work under grueling conditions in law firms that will reject large numbers of them in their quest for partnership, are sufficient enticements and formidable barriers to the type of change 
the LatCrit example, we hope, will help to nudge Latina/o studies and actions in law and policy away from just another iteration of assimilationist, self-interested, politics-as-usual, and toward something new, something better, something more reasonably calculated to promote social justice through knowledge-production and principled action. First, however, we provide a note of clarification regarding our understanding of some key points that frame and inform this ongoing LatCrit experiment in theory, community and praxis. ${ }^{25}$

With these background thoughts in mind, we focus our review below on jurisprudential experiments associated with different types of "outsiders" to legal academia, or to North American society at large. More specifically, we focus on the OutCrits' combination of traditional and nontraditional approaches to knowledge-production during the past two or so decades. ${ }^{26}$ In so doing, we reject the notion that any one model or set of practices is always superior to the rest, whether already in existence or yet to be imagined and invented. Instead, in this Afterword we seek only to identify basic approaches or "models" available to present (and future) scholars, activists, and decision-makers interested in the project of social justice in part through Latina/o legal studies: from our perspective, only with the landscape mapped and a sense of context in place, can we consider seriously the

that could transform law schools which, after all, are the location where the values of the profession are first inculcated. The pay and status attracts many new graduates even while the hegemonic environment stifles their work. The law schools' response to these corporate clients and alumni/ae force the choices of most new graduates as well as the choices of un/tenured professors in and out of the elite schools about what they will write about, where they will hope to publish, and whom they hope to influence. Struggling against power, privilege, and hierarchy within educational institutions is a highly enervating task and poses formidable obstacles for Latinas/os as relative newcomers into the legal academy. In our view, it is within this context that LatCrit's efforts must be examined and evaluated.

25 The organic interplay of community-building and related practices to substantive theorizing is reflected in the early LatCrit commitment to self-criticality, in which the synergies of theory, community, and praxis are evident: "Our antisubordination analyses and interventions must be trained not only on society, the academy, its institutions and our various communities, but also on ourselves and our work. To succeed in antisubordination solidarity, outsider scholars must practice internally the lessons and insights that we apply to others' structures, and we must learn continually from this internal focus to help us unpack and tranquilize cycles or patterns of subordinating behaviors that recur both within and beyond our immediate vicinity. This inward moment of self-reflection is part and parcel of our antisubordination work." Valdes, Theorizing "OutCrit" Theories, supra note 8, at 1269; see also infra note 14 and accompanying text (on criticality and self-criticality).

26 One reason that OutCrit scholars must undertake traditional scholarship even when they may be more drawn to more non-traditional forms is the taming and restraining functions played by the tenure system within universities. Experimenting with new forms of scholarship or giving voice to radical critiques would likely gain the opprobrium of more traditional or conservative tenured colleagues, who evaluate and vote on the promotion and tenure of scholars. See infra notes 55-62 and accompanying text (explicating "safe" and "dissenting"-or unsafescholarship under imperial regimes). 
best paths or approaches toward situating "Latinas/os" at the center of contemporary legal discourses for the original and ultimate LatCrit purpose of catalyzing, informing, and sustaining antisubordination collaborations capable of delivering, in due time, material social change. ${ }^{27}$

In this Afterword, we partially describe how LatCrit scholarly projects, practices, and norms reflect the "democratic" ("big tent") model of knowledge-production. Along the way, we compare and contrast this model, first, to the "imperial" (or "traditional") model and, then, to the "vanguardist" (or "safe space") model of knowledge-

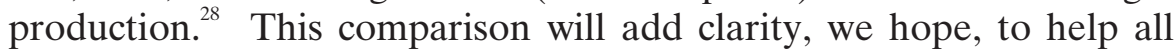

27 The initiation of Latina/o legal studies is an effort to place Latina/o voices, concerns, and communities at the center of social and legal analysis as part of the larger anti-subordination project. . . . LatCrit scholarship cannot be limited to "Latinas/os" in any essentialized sense. LatCrit identification need not hinge on ancestry or nationality. Rather, this identification flows from a willingness to center the "Latina/o" in social and legal discourse. The LatCrit subject position signifies a concern with Latina/o conditions and issues rather than with Latina/o roots or birth. Valdes, Under Construction, supra note 13, at 1137-38.

28 Again, in this Afterword, we sketch and describe the contours of each model only to contextualize our observations regarding the development of Latina/o legal studies. To do so, we must settle on some names, even if provisionally. In naming these models for reference in this Afterword, we again rely on our predecessors and contemporaries, aiming to build on their thoughts and words. In this provisional naming, we echo the work of other outsider critical scholars: Professors Richard Delgado, Angela Harris, and Sylvia Lazos Vargas. See infra notes 55,67 , and 95 .

It bears emphasis that, in using their terms below, we are invoking their uses and analyses as a convenient shorthand and an existing foundation for our descriptive, non-normative nomenclature. In particular, our use of Professor Harris's term ("vanguard") does not refer to political, philosophical, or ideological debates outside of the legal academy; echoing Professor Harris, we use it only to describe particular conditions of, or approaches to, the production of contemporary legal texts among North American academics. See infra note 66. Even if we cannot do so at every step, we acknowledge again, here at the outset, that LatCrit work has much in common with other politically progressive groups and movements, especially critical race theory and feminism: "LatCrit theory is supplementary, complementary, to Critical Race Theory. LatCrit theory, at its best, should operate as a close cousin-related to critical race theory in real and lasting ways. ..." Valdes, Practices to Possibilities, supra note 10, at 26-27 (introducing the Colloquium papers which occasioned the invention of the "LatCrit" moniker). Thus, in drawing distinctions with others based on models of knowledge production-and specifically with those who labor alongside us in the legal academy - we do so to explain our collective choices in democratic experimentation, which we think and hope build positively on the efforts of other critical outsider scholars.

It also bears emphasis that, in comparing and contrasting these models we do so in full recognition that the models are fluid constructs, which sometimes converge and overlap and other times diverge and differ. We understand as well that the different versions of each modelwhether SALT, critical legal studies, LatCrit, or LSA — themselves are fluid and complex, changing constantly over time, experimenting with elements of each model in differing ways at different times. Despite this multi-leveled fluidity and complexity, we think and hope that the summary descriptive capsules presented here will resonate with our readers, at least those familiar with the ways and means of the North American legal academy, enough to understand the position we take with respect to Latina/o legal studies. See the Appendix to this Afterword (present- 
scholars make (and remake) their own choices and practices, perhaps in more self-critical and self-conscious ways.

We do not doubt that this descriptive account could be told in other ways, and we invite other scholars to fill in the details we have missed here, or to tell a different story altogether. We likewise do not doubt or dispute that scholars can and do mix and match different aspects of each model tailored to particular moments or projects. Here we aim only to outline the basic contours of the three basic knowledge-production frameworks for contemporary legal discourses. In this way, we hope that diversely situated scholars interested in the continuing development of Latina/o legal studies can consider the landscape of current structures as they pursue their individual and collective knowledge-producing activities. Even more specifically, we hope in the space allowed to show how and why the LatCrit experiment in democratic knowledge-production serves as a helpful model for future generations in the ongoing development of Latina/o legal studies in the service of social justice activism, both within and beyond the legal academy of the United States, despite its limitations and shortcomings.

We likewise recognize that this account and analysis of the LatCrit experiment - like our sketch of the three "models"-is inevitably our own. But we also think the points and emphases presented below about the LatCrit project reflect broadly accepted understandings among LatCrit-identified scholars. To underscore our effort to be representative, we include quotes throughout this Afterword from a diverse group of LatCrit scholars interviewed in October 2007, during the Twelfth Annual LatCrit Conference ("LatCrit XII") that this symposium commemorates. Those interviews inaugurated a LatCrit Oral Histories Project, undertaken in response to repeated queries for information about organizational history, theoretical development, jurisprudential lineage, and the like. The scholars who spoke then help us now to illustrate democratic knowledge-production in action. Their eloquence underscores that the theoretical points we unfold below are not really our own-or certainly not only our own. Their eloquence affirms that our collective and individual commitments to these choices and practices are not inadvertent; rather they emerge out of a synergistic, trial-and-error process we have undertaken during the past dozen years in pursuit of the four interactive goals or functions of theory that early LatCrits proposed at the outset of this

ing two charts that provide an overview of the key characteristics we associate with each model to help distinguish among them). 
experiment. $^{29}$ This multi-vocal format, we hope and intend, will reflect and give expression to the principled openness that characterizes the LatCrit project in democratic knowledge-production. ${ }^{30}$

\section{KNOWLEdge PROduction Models: A BRIEF OVERVIEW}

We begin with acknowledging and underscoring some key limitations in the mapping exercise we undertake below. Because our aim is focused on situating the LatCrit experiment within the existing landscape of legal knowledge-production, we structure the account to bring the LatCrit location into sharp relief. Accordingly, we begin with the dominant model, and then unfold briefer accounts of the various alternatives to it, before training attention on the LatCrit record. This summary exercise thus tracks major historical and substantive developments in legal knowledge-production, as we understand them, in order to make LatCrit choices and practices more comprehensible. In this spirit, and to provide a quick visual overview, we include two charts in the Appendix to this Afterword, which depict the conceptual and operational features that constitute and distinguish the three major models of legal knowledge-production, as we are able to discern in the descriptive and analytical account we present here. We hope and intend, however, that this tentative sketch will be followed with richer accounts to help ensure the continuing vitality of innovative models and experiments in legal knowledgeproduction-efforts that, whether in existence now or waiting still to be imagined and invented, can be more consonant in fact with the basic values of dignity, liberty, and equality that this nation and profession formally embrace with much fanfare.

\section{A. The "Imperial" (or "Traditional") Model}

The mainstream or "imperial" tradition is as old as the establishment of formal legal education in the United States under the stilldominant structure of today. ${ }^{31}$ Under the influence of Langdellian

29 To view the LatCrit Oral Histories Project interviews of October 2007, see www.latcrit.org. See generally Valdes, Under Construction, supra note 13, at 1093-94 (providing an early discussion of these four jurisprudential functions); see also infra note 111 and accompanying text (elaborating further on this theme).

30 "This diverse effort to locate LatCrit in the broader landscape of critical theory can help elucidate and advance LatCrit theorists' original sense of collective and self-aware situatedness within the larger world of legal and outsider discourses." Valdes, Theorizing "OutCrit" Theories, supra note 8, at 1267 (outlining varying outsider approaches to theory-making and detailing LatCrit practices as a synthesis).

31 For a historical overview of the institutionalization of formal legal education in the United States, see Robert SteVens, LAW School: LEGAL EdUCATION IN AMERICA FROM THE 1850 S TO THE 1980S (1983); see also WILLIAM R. JOHNSON, SCHOOLED LAWYERS: A STUDY 
formalism and scientism, this tradition is riveted on legal doctrine as woven by appellate judges. But the original version of this modellike all other versions under the other models-has been in constant flux, even as it has become entrenched in its near-hegemonic form. During the first half of the last century, "realists" who sought to elevate the importance of social reality in the understanding and crafting of legal rules challenged the early premises and purist Langdellian practices of the mainstream, or traditional, model. ${ }^{32}$ They succeeded, making empiricism part of the modern imperial tradition as practiced today.

This "tradition" thereby became dominant in two basic, historical steps that also help to tell the story of the institutionalization and professionalization of legal education in the United States. The first of these steps, or "classical" stage, was characterized by extreme formalism and scientism: Langdellian purism. ${ }^{33}$ The second or "modern" stage is brought into view by the efforts of the Realists, with their sociological jurisprudence and empirical innovations, and (later) by the legal process scholarship and its emphasis on mechanics rather than outcomes. $^{34}$ Thus, the classical era emphasized internal doctrinal

In THE Clash of Professional Cultures (1978). For relatively contemporaneous accounts, see Josef Redlich, THE COMmon LAW AND THE CASE METHOD IN AMERICAN UNIVERSITY LAW SCHOOls (1914); Alfred ZANTZIGER REED, TrAining FOR THE PUBLIC PROFESSION OF THE LAW (1921); see also LAURENCE R. VEYSEY, THE EMERGENCE OF THE AMERICAN UNIVERSITY (1965) (focusing on the development of the university, more generally, rather than the law schools within them).

32 For various perspectives and accounts, see David P. Bryden, Scholarship about Scholarship, 63 U. Colo. L. REV. 641 (1992); Stephen M. Feldman, The Transformation of an Academic Discipline: Law Professors in the Past and Future (or Toy Story Too) 54 J. LEGAL EdUC. 471 (2004); Robert W. Gordon, Lawyers, Scholars, and the Middle Ground, 91 MICH. L. REV. 2075 (1993); Frank Munger, Mapping Law and Society, in Crossing Boundaries: Traditions AND Transformations In LAW AND SOCIETy RESEARCH 21 (Austin Sarat, Marianne Constable, David Engel, Valerie Hans \& Susan Lawrence eds., 1998); Richard A. Posner, The Deprofessionalization of Legal Teaching and Scholarship, 91 MICH. L. REV. 1921 (1993); Robert Post, Legal Scholarship and the Practice of Law, 63 U. COLO. L. REV. 615 (1992); George L. Priest, The Growth of Interdisciplinary Research and the Industrial Structure of the Production of Legal Ideas: A Reply to Judge Edwards, 91 MicH. L. REV. 1929 (1993); George L. Priest, Triumphs or Failings of Modern Legal Scholarship and the Conditions of Its Production, 63 U. Colo. L. REV. 725 (1992); John Henry Schlegel, A Certain Narcissism; A Slight Unseemliness, 63 U. Colo. L. ReV. 595 (1992); James Boyd White, Law Teachers' Writing, 91 MICH. L. REV. 1970 (1993). See generally Garth \& Sterling, supra note 11.

33 See STEVENS, supra note 31, at 35-72 (describing Langdell's influence as dean of Harvard Law School in establishing the "structure, content and style" of legal education and scholarship in this country, which today represents the dominant tradition).

34 For Realist texts of the era, see Roscoe Pound, The Scope and Purpose of Sociological Jurisprudence, 25 HARV. L. REV. 489, 516 (1912) (explaining that "the sociological jurist pursues a comparative study of legal systems, legal doctrines, and legal institutions as social phenomena, and criticizes them with respect to their relation to social conditions and social progress"). See also Karl N. Llewellyn, A Realistic Jurisprudence--The Next Step, 30 COLUM. L. REV. 431 (1930). Realists thus critiqued early version of the dominant or mainstream tradition-Langdellian 
logic, whereas realism and process sought to balance this skew with additional angles that would complement, not supplant, the ultimate concern with Law. Realists, as we outline below, aimed chiefly to bridge the gulf between law and society that they perceived as Langdellianism's major flaw-in other words, to make law more relevant to social realities as a problem-solving instrument. While neither can be homogenized into a simplistic monolith, each produced similar kinds of texts under similar kinds of conditions, even if inspired by different conceptions of law's very nature and social utility.

This traditional or mainstream corpus of scholarship was produced in tandem with the construction of formal legal education, specifically within a university setting, during the turn of the Nineteenth into the Twentieth Century. ${ }^{35}$ Thus, the conditions for the production of this traditional scholarship were bound up in the larger processes of core institution-building for the establishment of Law as "a true intellectual discipline," rather than (just) a valuable profession or vocation. This intertwining was both substantive and institutional, ensuring a thorough integration and domestication of legal scholarship in and through the project of constructing formal legal education in the United States. This scholarship inevitably reflected not only the intellectual state of Law during that time, but also the pulls and pressures of the conditions attaching to the broader project of creating a law school within a university, and later an association of them nationwide, not to mention also creating an association for their graduateslegal practitioners. ${ }^{36}$

Then, as now, this process pivoted on inter-group identity politics based on race, gender, ethnicity, immigration status, class, and related axes of social identification. This "traditional" practice of identity

\footnotetext{
purism - for its "mechanical" approach to the observable indeterminacy of legal rules, and for its failure to adopt a "functional" or realistic approach in light of known social realities. See, e.g., Roscoe Pound, Mechanical Jurisprudence, 8 Colum. L .REV. 605 (1908); Felix S. Cohen, Transcendental Nonsense and the Functional Approach, 35 COLUM. L. REV. 809 (1935); Karl N. Llewellyn, On What is Wrong with So-Called Legal Education, 35 CoLUM. L. REV. 651 (1935). For historical accounts of the Realist experiment in innovative knowledge production, see LAURA KALMAN, LEGAL REALiSM AT YALE, 1927-1960 (1986); William TWINING, KARL LlEWELLYN And the ReAlist Movement (1973); John Henry Schlegel, American Legal Realism and Empirical Social Science: From the Yale Experience, 28 BUFF. L. REV. 459 (1979). For a LatCritical sketch of this period and its significance to outsider scholarship, see Hernández-Truyol et al., infra note 67, at 172-77; see also STEVENS, supra note 31, at 155-71.

35 See STEVENS, supra note 31, at 73-154 (describing this process of consolidation and institutionalization regarding legal culture and legal theory); see also John Henry Schlegel, Between the Harvard Founders and the American Legal Realists: The Professionalization of the American Law Professor, 35 J. LEGAL EdUC. 311 (1985) (providing an account focused on developments leading from the Langdellian to the Realist eras).

36 See supra note 31 and sources cited therein (on the establishment of universities and law schools in the United States).
} 
politics was designed consciously, openly, and explicitly to create structural privilege for white, native, Christian men, and formal exclusion for nonwhites, immigrants, Jewish individuals, and women in the formation of a legal culture in this country. ${ }^{37}$ For example,

In 1922 the Yale Board of Admissions was deeply concerned about the 'Jewish problem.' In that same year, a Yale psychologist warned the state bar association that 'this invasion of foreign stock' was undermining 'the finer professional spirit and feeling which characterizes the professional training of the typical American lawyer.' Dean Swan of the Yale Law School suggested to the state bar in 1923 that students with foreign parents should be required to remain longer in college than native-born Americans before being admitted to law school. At a Yale faculty meeting in the same year, Swan argued against using grades as a basis for limiting enrollment to the law school, because such a development would admit students of 'foreign' rather than 'old American' parentage, and Yale would become a school with an 'inferior student body ethically and socially. ${ }^{, 38}$

This exemplar shows the interlinked operation of racism, nativism, and related supremacies based on familiar categories of identity.

Moreover, this sort of unabashed, result-oriented fixation on the preservation of colonial stratification in multidimensional terms was not an isolated aberration limited to Yale, or to the East Coastalthough this exemplar does quite aptly illustrate concretely how the conscious choices and acts of yesteryear entrenched the elitist realities that still dominate the profession today in the form of imperial traditions: indeed, as the well-documented history of legal culture in this country shows, this sort of undisguised, premeditated course of action motivated and directed the formal constitution of legal culture in the United States in the schools, universities, associations and networks being erected during those times from coast to coast, in both public

37 For a LatCritical account, published in one of the early LatCrit symposia, see Daria Roithmayr, Deconstructing the Distinction between Bias and Merit, 85 CAL. L. REV. 1449, 147594 (1997) (describing the efforts to privilege native-born white, Christian males in legal education and practice through the creation of bar associations and the like); see also STEVENS, supra note 31, at 73-130 (providing a similar, more detailed, account of this identity-inflected process). For a pictorial history of some milestones in women's struggles to obtain a legal education, including the establishment of single-sex institutions in the late nineteenth century, see http://library.law.columbia.edu/rise_of_women/education/bulletin.html (last visited on July 4, 2008). Dr. Emily Kempin formally opened the first class in law for women at the Women's Legal Education Society (later New York University School of Law) on October 30, 1890. http://library.law.columbia.edu/rise_of_women/education/kempin.html (last visited on July 4, 2008).

38 STEVENS, supra note 31 , at 101. 
and private educational settings, precisely with those exclusionary ends uppermost in mind. ${ }^{39}$ Thus was the architecture and construction of "merit" in legal culture in the United States accomplished and corrupted, all at once-a naked effort to protect established elites against more able newcomers based squarely and vocally on notions or ideologies of identity. Thus was the imperial tradition, against which we struggle today, shaped and ensconced in the innocuous but hypocritical name of morals, ethics, standards, and other assertedly "American values." ${ }^{40}$

The invention and imposition of "standards" in legal knowledgeproduction was, in other words, a thoroughly neocolonial project of identity politics. These neocolonial politics expressly sought to advantage and entrench identity-related privileges based on "original" or traditional colonial patterns, even as the nation industrialized and absorbed immigrants from southern and eastern Europe-economic and social changes that threatened the ruling classes that had sprung up and taken hold in the intervening decades. At that time, as the passage above illustrates, the architects and creators of legal culture's core institutions, like the American Bar Association (ABA), the Association of American Law Schools (AALS) and the nation's university-based law schools, touted this invidious purpose in public statements and documents, which survive today as bulwarks against willful amnesia of this oppression, and of the present-day legacies still embedded in the very substance and structure of their creation. This traditional form of explicit and calculated identity politics in the construction of legal culture, education, and scholarship in the United States was therefore very much not of the "unconscious" type that continues to propel those formative skews today in the form of institutionalized racism, sexism, and related traditions of identity privilege and subordination in United States law and society. ${ }^{41}$

As a result of these professional, institutional, and ideological drives, the conventional texts of both the classical and modern mainstreams provide what we now consider the "archetype" of the "typical

39 For a thorough historical account that covers class-based, race-based, sex-based, immigration-status based, and religion-based ideologies invoked to structure the design and details of legal institutions, see Jerold S. Auerbach, UnEQual Justice AND SOCIAL Change IN MODERN AMERICA (1976).

40 See, e.g., Roithmayr, supra note 37, at 1475-94.

41 For the paradigmatic articulation of this concept, see Charles Lawrence, III, The Id, the Ego, and Equal Protection: Reckoning with Unconscious Racism, 39 STAN. L. ReV. 317 (1987) (setting out the concept of "unconscious racism" in law and culture); see also Symposium, Unconscious Discrimination Twenty Years Later: Application and Evolution 40 CONN. L. REV. 927 (2008); Charles Lawrence III, Unconscious Racism Revisits: Reflections on the Impact and Origins of the Id, the Ego, and Equal Protection, 40 CONN. L. REV. 931 (2008). 
law review article" against which everything "nontraditional" must struggle. Given the pervasiveness of neocolonial identity politics in the formalization of law and legal culture in the United States, this scholarship archetype-like legal culture more broadly- is genetically racialized, ethnicized, sexed, and otherwise constructed as a mirror image of the then-and-still prevailing supremacies, based precisely on mainstream ideologies of race, ethnicity, sex, and other such markers. This archetype inevitably reflects in myriad ways the customs of the dominant identities and ideologies, which since then have become thoroughly encrusted on the whole of legal culture in ways that some mistake as simply natural and value-neutral. Though the invidious politics of identity embedded in the DNA of this archetype are no longer openly touted, as they were a century ago during the early stages of Law's formalization, they remain very much in place and help to determine in crucial ways the operation of legal culture in micro and macro terms each day from coast to coast. ${ }^{42}$

This archetype has been variously described by scholars of differing perspectives in surprisingly uniform terms, and reflects the original version of such a text-the first "article" in the first volume of the Harvard Law Review, devoted to common law puzzles of logic and doctrine relating to the role of equity in certain commercial transactions. $^{43}$ One typical and relatively recent mainstream description of this archetypal approach to legal scholarship casts the original version of the imperial tradition in this way:

Langdellian scholars would begin either by stating, in the abstract, a small number of axiomatic principles or by analyzing a series of cases to discover, through inductive reasoning, the necessary axiomatic principles. Those principles then could govern all possible disputes within the relevant field of law. More specific legal rules and correct resolutions of legal issues could be deduced, through abstract logical reasoning, from the principles. Ultimately the common law could be logically arranged into a formal and conceptually ordered system. ${ }^{44}$

42 See infra notes 57-61 and accompanying text (on "safe" scholarship and the imperial tradition). For a description of how law school with its "case law positivism" has a political, ethical, psychological and intellectual homogenizing effect on law students and law professors, see Pierre Schlag, The Anxiety of the Law Student at the Socratic Impasse: An Essay on Reductionism in Legal Education, 31 N.Y.U. REV. L. \& Soc. CHANGE 575 (2007).

43 To review the original version of the archetype, see J.B. Ames, Purchase for Value Without Notice, 1 HARV. L. REV. 1 (1887). For a sampling of descriptions of this archetype since then, see infra note 50 and sources cited therein (on the imperial tradition and alternatives to it).

44 Feldman, supra note 32, at 476. 
These texts thus focused on classification systems that mimic scientific method and are characterized generally by an emphasis on the internal logic of legal structures, rules or principles; although one important modern development within this model has been the introduction of empirical and economic sources of knowledge through Realism and related developments. The aim of this original and continuing tradition in North American legal scholarship was/is "tinkering"incremental legal reform, whether by judicial, legislative, administrative, or other action, in order to attain the ideals of formal/procedural justice.

Given these historical, structural, and institutional circumstances, mainstream or traditional scholarship has been produced usually by atomized scholars encased in their "home" institutions - the very core institutions built in tandem with the traditions of this mainstream scholarship. The tenets or purposes of this model include, of necessity, a basic belief in relatively stable legal and social categories. The substantive focus of this body of scholarship is mostly on the judicial opinions of appellate judges; the focus is doctrinal and the concern is Law. This scholarship, at bottom, pursues only the ideal of formal justice, or procedural justice, rather than particular kinds of outcomes cognizant of social problems and relevant realities. In this body of contemporary discourse, social conditions and identities tend to be formally marginal, if not irrelevant, to the application of supposedly neutral and scientific rules in varied factual settings. ${ }^{45}$

By the 1970s, in the wake of the post-World War II period and the social ferment of the1960s, this imperial tradition was adrift, if not stagnant, in the eyes of many contemporary observers. ${ }^{46}$ Some of the complaints we encounter or express today, like some of the complaints that the Realists leveled at the system nearly a century earlier, are found in the critiques and exchanges of those days, and especially the 1970s and 1980s. ${ }^{47}$ The emergence of democratic or vanguard experiments during those two decades thus comes as little surprise, at

45 In light of the salience of neocolonial identity politics in the construction of legal culture and its norms of knowledge and knowledge production, this erasure of identity of course was strategic and Orwellian. This two-step combination of salience and erasure effectively ensured that the practice of identity politics under the imperial model would systematically elevate the preferred identities and "invisibilize" all "others." See supra notes 37-40 and sources cited therein (on the salience of neocolonial identity politics in the invention and imposition of norms and standards in the legal culture of the United States).

46 For a sampling of views from or about those times, see infra notes 86-89 and sources cited therein (providing commentary on the state of legal education and scholarship by the 1970s).

47 See supra notes 34-36 and sources cited therein (providing a sampling of Realist complaints); see also supra note 37 and sources cited therein (outlining some of our complaints). 
least from a LatCritical perspective. ${ }^{48}$ These circumstances illustrate that each of those experiments were formed as an expression of disenchantment with the imperial status quo at that time, just as LatCrit theory has done during the past dozen years. ${ }^{49}$ Apart from this root commonality, however, each of the experiments arising during that period of widespread disenchantment with imperial ways took shape differently, due, in great part, to the varied circumstances and choices at their respective points of origin and early development.

Nonetheless, testifying to the power of history and structure, today many individual scholars continue working within this dominant tradition. Typically, many contemporary legal scholars still develop their ideas in relative isolation and then present them to audiences (usually) of other academics-often in the form of the conventional faculty seminar or academic conference circuit, which in turn is organized around core institutions associated with this sort of scholarship: law schools, etcetera. Therefore, the form of the texts produced under these still-prevalent conditions cannot help but become, as it now has, the very definition of the traditional law review article. ${ }^{50}$

At least two important developments have disrupted this tradition of mainstream scholarship in the recent decades since the 1970 s

48 See infra notes 67-93 and accompanying text (sketching the emergence of vanguard and democratic experiments during the same decades of the 1970s and 1980s).

49 For further elaboration, see Frank Valdes, Rebellious Knowledge Production, Academic Activism and Outsider Democracy: From Principles to Practices in LatCrit Theory, 1995-2008,

_U. SEAtTLE L. REV.___ (forthcoming 2010) (presenting a historical and intellectual account of LatCrit values, principles and practices).

50 For an illuminating and recent historical overview, see STEPHEN M. FELDMAN, AMERICAN LEGAL THOUGHT FROM PREMODERNISM TO POSTMODERNISM: AN INTELLECTUAL VOYAGE (2000). For background readings from different perspectives on the state of legal scholarship during the time that this tradition came under critical and outsider challenges, see Roy L. Brooks, Civil Rights Scholarship: A Proposed Agenda for the Twenty-First Century, 20 U.S.F. L. REV. 397 (1985); Stephen B. Burbank, Introduction: “Plus Ça Change..?”, 21 U. MICH. J.L. REFORM 509 (1987); John, S. Elson, The Case Against Legal Scholarship or, If the Professor Must Publish, Must the Professor Perish?, 39 J. Legal Educ. 343 (1989); Peter Gabel \& Duncan Kennedy, Roll Over Beethoven, 36 StAN. L. REV. 1 (1984); David L. Gregory, The Assault on Scholarship, 32 WM. \& MARY L. REV. 993 (1990); Janet Gumm, Chicago-Kent Law Review Faculty Scholarship Survey, 66 CHI.-KENT L. REV. 509 (1990); Judith S. Kaye, One Judge's View of Academic Law Review Writing, 39 J. LEGAL EdUC. 313 (1989); Mark Kelman, The Past and Future of Legal Scholarship, 33 J. LEGAL EdUC. 432 (1983); Kenneth Lasson, Scholarship Amok: Excesses in the Pursuit of Truth and Tenure, 103 HARV. L. REV. 926 (1989); Gary Minda, The Jurisprudential Movements of the 1980s, 50 OHIO ST. L.J. 599 (1989); George L. Priest, The Increasing Division Between Legal Practice and Legal Education, 37 BUFF. L. REV. 681 (1988); Edward L. Rubin, The Practice and Discourse of Legal Scholarship, 86 MiCH. L. REV. 1835 (1987). See generally Symposium on Legal Scholarship: Its Nature and Purposes, 90 YALE L.J. 955 (1980). Perhaps the original expression of recurrent themes in more recent legal scholarship about legal scholarship is best captured in Fred Rodell, Goodbye to Law Reviews, 23 VA. L. REV. 38 (1936) (famously declaring that legal scholarship had only two shortcomings: content and style, and declaring a halt to further publications on his part in traditional law reviews). 
leading up to this jurisprudential moment: the creation of clinics within law schools, and the emergence of critical scholarship, including critical outsider (or OutCrit) scholarship. These two developments share a common interest in reforming the parameters and priorities of legal education, substantive doctrine, and law practice. Although both are reformist, or oppositional, they concentrate their primary efforts on different aspects of the status quo.

The clinical movement, originally a curricular innovation, deserves emphasis because in the last decade it has spawned a veritable deluge of related scholarship, much of it exploring the representation of clients from subordinated communities. This scholarship is a penetrating critique of the legal doctrine, institutions-such as courts and law schools - and practices, which are all flawed or limited in their capacity to diminish the structural inequalities that create or add to many of the legal problems that face the clients seen by law clinics. ${ }^{51}$ This movement, while variegated, aims to intervene most specifically at the point where law students internalize their preparation to become legal practitioners. Thus, while uniquely focused on issues of legal representation and social equity, as reflected in both the practice and doctrine of law, clinical scholarship, during the past couple of decades, oftentimes has been effectively critical of the broader lawand-policy status quo. In this way, clinical scholarship contributes significantly to the knowledge-producing efforts of legal academics.

In even more recent years, since the second disruption of traditional scholarship_namely the emergence of critical and outsider scholarship in the 1980s-the premises and methods of this mainstream scholarship have been interrogated frontally and vigorously in broad and fundamental theoretical terms. Outsider law students, often armed with insights and analyses found in this innovative scholarship, have been powerful allies in the interrogation of these mainstream traditions, often abandoning established journals with their elitist and exclusionary practices and creating new journals dedicated

51 See, e.g., Sameer Ashar, Law Clinics and Collective Mobilization, 14 CLINICAL L.REV. 355 (2008); Public Interest Lawyers and Resistance Movements, 95 CAL. L. REV. 1879 (2007); Christine Zuni Cruz, Four Questions on Critical Race Praxis: Lessons from Two Young Lives in Indian Country, 73 Fordham L. Rev. 2133 (2005) (hereafter "Four Questions). Anthony V. Alfieri, (Un)Covering Identity in Civil Rights and Poverty Law, 121 HARV. L. REV. 805 (2008); Clinical Genesis in Miami: Introduction, 75 U.M.K.C. L. Rev. 1137 (2007); Faith in Community: Representing "Colored Town", 95 Cal. L. Rev. 1829 (2007); Beth Lyon, Changing Tactics: Globalization and the U.S. Unauthorized Immigrant Worker Rights Movement, _ UCLA J. INT'L L. FOR. AFF. _ (forthcoming 2008); Tipping the Balance: Why Courts Should look to International and Foreign Law on Unauthorized Immigrant Worker Rights, 29 U. PA. J. INT'L L. 169 (2007); Farm Workers in Illinois: Law Reforms and Opportunities for the Legal Academy to Protect Some of the State's Most Disadvantaged Workers, 28 S. ILL. U. L.J. 263 (2005). 
to the pursuit of oppositional scholarship. ${ }^{52}$ This combination of scholarly and student activism fueled the steady process of interrogation and innovation leading to the very emergence of critical and outsider scholarship as we know it today. ${ }^{53}$ Indeed, this multifaceted process of interrogation and innovation has been constitutive of the nontraditional methodologies and oppositional stances taken so often in the various genres of critical and outsider scholarship that have unfolded in their own particular ways since the 1980s; this process has helped to mark even the most formative points and times of "rupture" between dominant traditions and innovations from outside or below. This recent and ongoing process of theoretical interrogation and intellectual innovation also yielded the moment that names the dominant model and its archetypal expressions.

In a groundbreaking 1984 study of mainstream legal scholarship, Professor Richard Delgado set out to "explain the tradition" of what he termed "imperial scholarship" - a term we adopt here to name this dominant model based on resilient Langdellian vestiges. Analyzing in detail the "exclusionary scholarship" of elite mainstream traditions and networks, Professor Delgado mapped "an inner circle of about a dozen white, male writers who comment on, take polite issue with, extol, criticize, and expand on each other's ideas." ${ }^{55}$ Non-traditional scholarship, especially if authored by outsiders or critics, he observed,

52 For some short histories of law journals created and maintained by outsider law students, see these websites of selected journals: University of Michigan Journal of Race and Law, http://students.law.umich.edu/mjrl/ (last visited July 1, 2008); Harvard Blackletter Law Journal, http://www.law.harvard.edu/students/orgs/blj/ (last visited July 1, 2008); Berkeley La Raza Law Journal, http://www.boalt.org/LRLJ/ (last visited July 1, 2008); Chicana/o Latina/o Law Review, http://www.law.ucla.edu/cllr/ (last visited July 1, 2008). For a more detailed discussion of these developments, see supra note 5 and accompanying text.

53 See supra notes 50-51 and sources cited therein (on critical and outsider works).

54 See, e.g., Symposium, Minority Critiques of Critical Legal Studies Movement, 22 HARV. C.R.-C.L. L. REV. 297 (1987) (the papers published in this symposium reflect and project the main moment of rupture between CLS and scholars that later formed CRT); see also Symposium, The 1985 Minority Law Teachers Conference, 20 U.S.F. L. REV. 383 (1985) (presenting a collection of papers that capture prevailing conditions at that historical moment). For a contemporaneous account focused on the role of students and diversity in the fomenting of these ruptures, see Sumi Cho \& Robert Westley, Historicizing Critical Race Theory's Cutting Edge: Key Movements that Performed the Theory, in CrossroAds, Directions, AND A NEW Critical RACE THeOry 243 (Francisco Valdes, Jerome McCristal Culp \& Angela P. Harris eds., 2002) at 32 [hereinafter CRT CROSSROADS]. For further discussion of these developments, see infra notes 66-81 and accompanying text (describing the emergence of Critical Legal Studies and Critical Race Theory in the form of the vanguard, or safe space, model).

55 Richard Delgado, The Imperial Scholar: Reflections on a Review of Civil Rights Literature, 132 U. PA. L. REV. 561, 562-63 (1984) [hereinafter Delgado, Imperial Scholar] (emphasis in original). For a follow-up on this study, see Richard Delgado, The Imperial Scholar Revisited: How to Marginalize Outsider Writing, Ten Years Later, 140 U. PA. L. REV. 1349 (1992). 
... seems to have been consigned to oblivion. Courts rarely cite to it, and the legal scholars, whose work really counts, almost never do. The important work is published in eight or ten law reviews, and is written by a small group of professors, who teach in the major law schools.

Professor Delgado's study effectively depicts how this work, as a whole, continues to focus, as it did a nearly century ago, on the rules of law that appellate judges spin, and whether their spinning, in the form of opinions, can survive the scrutiny of mainstream scholarly logic, oftentimes, quite apart from observable social realities and consequences. Though his study was focused on a sub-part of the traditional, or mainstream, legal literature on constitutional rights, this "elaborate minuet" captures the refined essence of the imperial model in operation then and today. ${ }^{56}$

For example, in continuing to elucidate this dominant or mainstream tradition, contemporary scholars have mapped the contours of "safe" and "dissent" forms of legal scholarship in order to unpack the causes and dynamics of historical skews under the imperial model that generally affect present-day practices and perceptions throughout the legal academy of the United States. ${ }^{57}$

Legal scholarship is shaped by the socially dominant members of society. In the United States, this means that, at least until the 1970s and 1980s, when women and people of color entered the academy (in significant numbers), legal scholarship was shaped by white men. This means that the ideologies and methodologies of 'traditional doctrinal scholarship' are informed by the decades in which the legal academy consisted of white, upper-middle class men. In light of this historical bias, it seems appropriate to question whether safe scholarship is the dominant standard for legal

56 Id. at 563.

57 "Safe scholarship is defined as scholarship that conforms to the ideologies, methodologies, and standards shared by the evaluator or the 'mainstream' legal academy during a specific time period. For example, prior to 1950, one form, and arguably the predominant form, of safe scholarship was doctrinal scholarship ... historically developed based on the values and norms of the predominantly male, middle- or upper-middle class members of the legal academy. One might even take this to signify the ideologies and methodologies of 'mainstream' scholarship up until circa the 1970s and 1980s, when feminist and critical race theorists emerged." Rachel J. Anderson, From Imperial Scholar to Imperial Student: Minimizing Bias in Article Evaluation by Law Reviews, 20 HASTINGS WOMEN's L. J. (forthcoming 2009). In contrast, “dissent scholarship is defined as scholarship that uses ideologies, methodologies, perspectives, viewpoints and voices or other standards that are competing with the evaluator's or the 'mainstream' ideologies and methodologies of the legal academy." $I d$. 
scholarship solely because of fair competition and merit, or due to other factors.

These decades-long, and still-recent, histories of de jure exclusion and de facto marginalization in legal knowledge-production have entrenched the imperial hierarchy of legal scholarship and education today. They generate/d "a bias toward safe scholarship" that, in turn, "skews the legal discourse" because dissenting scholars "that do not conform to the norms and standards of safe scholarship are more likely to be systematically excluded from the status and reputationbearing discourse located in the pages of law reviews." Equally important, "[w] hether this is willful or unintended, it results in a lack of a level playing field in the evaluation of legal scholarship." ${ }^{59}$

It bears emphasis that these traditional and continuing skews combine to produce a consistent and systematic effect even today: "the perpetuation of a bias for the historically dominant, uppermiddle class thinking patterns and writing styles" that Professor Delgado denominated "imperial" when considering, two decades and half ago, the practices and patterns of mainstream, or safe, scholarship in the pages of the nation's leading law reviews, aiming precisely to discern whether those skewed patterns were/are the product of "merit" or bias. Moreover, this inequality survives the ephemeral fads with which the mainstream takes note of an emergent dissenting voice from time-to-time, like a child with a new toy.

For example, at one time critical race scholarship was 'hot' and therefore a case could be made that it was safe scholarship during that time. One also might argue that critical race scholarship has gone out of fashion again and, thus, has returned to the status of dissent scholarship. ${ }^{60}$

This "out-in-out" dynamic may help propel some particular texts, or individual authors, into relatively safe positions within the imperial hierarchy, which can secure helpful outsider gains within the legal academy; but, experience shows that this fleeting kind of interest leaves intact the power and structure of the hierarchy, itself, along with its biases, skews and unlevel playing fields. ${ }^{61}$

$58 \quad$ Id.

59 Id. Importantly, Professor Anderson draws on her personal experience as an editor at three different law journals at Boalt Hall School of Law, one of the nation's highest-ranked schools.

60 Id.

61 Id. For similar views, see Bruce A. Ackerman, The Marketplace of Ideas, 90 YALE L.J. 1131 (1980) (examining "fame" and its acquisition through scholarship as the "second currency" in the legal academy of the United States); Philip C. Kissam, The Evaluation of Legal Scholarship, 63 WASH. L. REV. 221 (1988) (describing the indeterminacy of "quality" as constructed by 
Today, perhaps the most prosperous iteration of this traditional mainstream model is represented by the body of texts understood as "law and economics." This field, also emergent during the 1980s, combines the focus on doctrine with a priority on particular notions of economic efficiency, which thus inclines this scholarship toward interdisciplinarity-a stance toward law and legal scholarship generally similar to that of the Realists. ${ }^{63}$ As with mainstream texts of prior eras, this scholarship is produced under similar conditions, and with the similar aim of shaping formal Law itself into a coherent whole, this time pivoting on its own construction of "efficiency": by and large, this contemporary field is produced by atomized scholars focused on core or mainstream venues, and audiences of powerful legal actors generating a constellation of stars and circuits, who set "stan-

imperial or traditional standards of legal scholarship); Edward G. White, The Text, Interpretation, and Critical Standards, 60 TEX. L. REV. 569 (1982) (presenting similar observations). Findings very similar to these analyses of structural imperial elitism are reported in various empirical studies measuring the "influence" of legal scholarship in traditional terms-that is, in terms of citation in appellate opinions. See, e.g., Louis J. Sirico, Jr. \& Jeffrey B. Marguiles, The Citing of Law Reviews by the Supreme Court: An Empirical Study, 34 UCLA L. REV. 131 (1986); Louis J. Sirico, Jr. \& Beth A. Drew, The Citing of Law Reviews by the United States Courts of Appeals: An Empirical Analysis, 45 U. MIAMI. L. REV. 1051 (1991). For additional background reading on the construction of "legal scholarship" under the traditional "standards" of the mainstream law review process, see Jordan H. Leibman \& James P. White, How Student-Edited Law Journals Make Their Publication Decisions, 39 J. LEGAL EDUC. 387 (1989).

62 For background readings on law and economics, see RICHARD A. POSNER, ECONOMIC ANALYSIS OF LAW (7th ed. 2007); RICHARD O. ZERBE, JR., ECONOMIC EFFICIENCY IN LAW AND ECONOMICS (2001); LAW AND ECONOMICS: THEORETICAL AND METHODOLOGICAL Foundations 1 (Richard A. Posner \& Francesco Parisi eds., 1997).

63 Law and economics, like Realism, seeks to make law a problem-solving instrument cognizant of real-life problems, but prioritize their view of economic "efficiency" as the gauge for determining the "best" approach to the resolution of real-life problems. See, e.g., Guido Calabresi, About Law and Economics: A Letter to Ronald Dworkin, 8 HofSTRA L. ReV. 553 (1979); Ronald Dworkin, Why Efficiency? A Response to Professors Calabresi and Posner, 8 Hofstra L. ReV. 563 (1979); Mario J. Rizzo, The Mirage of Efficiency, 8 Hofstra L. REV. 641 (1979). Yet, whereas the Realists focused on social practicality or "functionality," today's lawand-economics scholarship reduces that notion to "efficiency" based on economic cost-benefit analyses. These analyses, though purportedly designed to solve real-life problems in real-life terms, oftentimes embrace manifestly unrealistic or erroneous assumptions about human behaviors and social conditions contrary to that stated aim. For representative scholarship that identifies and analyzes such erroneous assumptions, see Shubha Ghosh, Property Rules, Liability Rules, and Termination Rights: A Fresh Look at the Employment at Will Debate with Applications to Franchising and Family Law, 75 OR. L. REV. 969 (1996); ROBIN PAUL MALLOY, LAW AND MARKET ECONOMY: REINTERPRETING THE VALUES OF LAW AND ECONOMICS (2000); Emily M.S. Houh, Critical Interventions: Toward An Expansive Equality Approach To the Doctrine Of Good Faith in Contract Law, 88 CORNELL L. REV. 1025 (2003). This gap between stated goals and choices of methodology renders law and economics suspect as ideology dressed up as scholarship - a feature of mainstream practices in the formation and operation of the imperial tradition. See, e.g., Linz Audain, Critical Cultural Law and Economics, the Culture of Deindividualization, the Paradox of Blackness, 70 IND. L.J. 709 (1995); Ian Ayres, Never Confuse Efficiency with a Liver Complaint, 1997 WIS. L. REV. 503 (1997). 
dards" and to whom everyone else defers or aspires. ${ }^{64}$ Like other jurisprudential experiments, law and economics cannot be reduced to a single monolithic entity ${ }^{65}$ but, in our view, its salient characteristics and practices, as well as its principal modes of production, represent the clearest and most vigorous extension of the imperial model in the context of a contemporary legal discourse.

\section{B. The "Vanguardist" (or "Safe Space") Model}

In the second half of the past century, as we indicated above, the Realists were succeeded by "critical" scholars who took that challenge of mechanical scientism several steps further. These critical scholars, through their innovative efforts, eventually gave rise to a "vanguardist" model for the production of legal knowledge, which emphasized conditions of production focused on small "safe" spaces of critical inquiry and exchange. Within the general category of contemporary legal discourses, we think that critical legal studies (CLS) and critical race theory (CRT) aptly help to illustrate this model. These vanguard experiments aimed to create venues safe for the production of dissenting scholarship in the same ways that the mainstream institutions of the legal academy, including law reviews, are supportive of safe scholarship. Indeed, we borrow the "vanguard" concept to name this second model from Professor Angela Harris, a scholar prominently associated with race, feminist and critical scholarship, who employs this term to describe specifically the structure and operation of critical race theory during the 1980 s and 1990 s. $^{66}$

The tenets and premises of this vanguardist body of "critical" scholarship proceed from a fundamentally skeptical view of the status

64 See, e.g., R. H. Coase, The Problem of Social Cost, 3 J.L. \& ECON. 1 (1960); Guido Calabresi, Some Thoughts on Risk Distribution and the Law of Torts, 70 YALE L.J. 499 (1961); Richard A. Posner, ECONOMIC ANALysis of LAW (1972); THE Origins of LAW AND ECONOMICS: ESSAYS BY THE FOUNDING FATHERS (Francesco Parisi \& Charles K. Rowley eds., 2005).

65 For other scholarship in law and economics that dissents from some of these attributes, see Emma Coleman Jordan \& Angela P. HARris, ECONOMic Justice: Race, Gender, IDENTITY AND ECONOMICs (2005); Jon Hanson \& David Yosifon, The Situation: An Introduction to the Situational Character, Critical Realism, Power Economics, and Deep Capture, $152 \mathrm{U}$. PA. L. REV. 129 (2003); Cass R. Sunstein, Social Norms and Social Roles, 96 Colum. L. REV. 903 (1996); Ian Ayres, Further Evidence of Discrimination in New Car Negotiations and Estimates of its Cost, 94 MicH. L. REV. 109 (1995); Bruce A. Ackerman, Law, Economics and the Problem of Legal Culture, 1986 DUKE L. J. 929 (1986).

66 See Angela P. Harris, Remarks at the LatCrit-SALT Faculty Development Workshop, Twelfth Annual LatCrit Conference, Miami, Florida (Oct. 5, 2007). See generally Berta Hernández-Truyol, Angela P. Harris \& Francisco Valdes, Beyond the First Decade: A ForwardLooking History of LatCrit Theory, Community and Praxis, 26 CHICANO-LATINo L. ReV. 237 (2006) (providing a jurisprudential history from a LatCritical perspective). 
quo and accommodationist (or celebratory) explanations of it. ${ }^{67}$ Rejecting the natural, inevitable, or essential condition of the status quo, critical scholarship produced under this model is characterized by a belief in social construction, rather than in the universal or stable categories of the traditional, or mainstream, model ${ }^{68}$ Though, like the imperial model of the mainstream, vanguardist scholarship frequently focuses on cases, it also focuses on social realities and critical theorizing to explain and change them-including the social realities implicated in various potential outcomes. ${ }^{69}$ This emphasis on, or linkage of, the legal with the social is accompanied by a great awareness of, or emphasis on, substantive and distributive justice (or, again, on outcomes), rather than simply on procedural regularity and formal justice. $^{70}$ This emphasis, or linkage, also facilitates interdisciplinarity to supplement in significant and substantial ways-and from a critical perspective-the "case crunching" that was/is typical of mainstream, or traditional, scholarship. ${ }^{71}$ For similar reasons, in this body of schol-

67 See generally Duncan Kennedy, A CRITIQue of AdJudicAtion: Fin de SiECle (1997). For an elaboration of these points from a CRT perspective, see Angela P. Harris, Jurisprudence of Reconstruction, 82 CAL. L. REV. 741 (1994). For another elucidation of criticality as stance in vanguard scholarship, from a CLS perspective, see Mark Tushnet, Critical Legal Studies: A Political History, 100 YALE L.J. 1515 (1991).

68 See, e.g., Ian F. Haney Lopez, The Social Construction of Race: Some Observations on Illusion, Fabrication, and Choice, 29 HARV C.R.-C.L. L. REV. 1 (1994). For an engaging review of this phenomenon, see Arthur Austin, The Postmodern Infiltration of Legal Scholarship, 98 MiCH. L. REV. 1504 (2000).

69 See, e.g., Mari Matsuda, Beyond, and Not Beyond, Black and White: Deconstruction has a Politics, CRT CROSSROADS, supra note 54, at 393 (emphasizing that all critical analysis produces foreseeable socio-political consequences). For a similar, earlier example, see Mari J. Matsuda, Looking to the Bottom: Critical Legal Studies and Reparations, 22 HARV. C.R.-C.L. L. REV. 323 (1987) (examining the legal issues surrounding reparations in light of relevant socio-legal realities and ramifications.

70 See, e.g., Charles R. Lawrence, Two Views of the River: A Critique of the Liberal Defense of Affirmative Action, 101 COLUM. L. REV. 928 (2001) (elaborating a critical and substantive analysis of legal debates and social realities surrounding remedies for racial subjugation).

71 This feature, of course, builds on the earlier inroads of the Realists. See supra text accompanying notes 34, 36 (on Realists' efforts to reform the mainstream tradition). For an early argument about the value of interdisciplinarity- the practice of linking legal approaches with those of other disciplines, see Law as Social Science, in AMERICAN LEGAL REALISM 232 (William W. Fisher, III, Morton J. Horwitz, \& Thomas A. Reed eds., 1993) (progressive scholars in the late 1920s experimented with the notion, finally discarded, that the social sciences and the emerging quantification of knowledge through statistics could advance social progress). For evidence of interdisciplinarity in judicial opinions, see Brief for Defendant filed by Louis Brandeis and Josephine Goldmark, Muller v. Oregon, 208 U.S. 412 (1908). So-called "Brandeis briefs," later filed in Brown v. Board. of Education and several cases decided by the Warren Court, relied on information and methods used by sociologists, psychologists, historians and scholars from other disciplines. Id. at 237. For samples of skeptical mainstream commentaries on interdisciplinarity in legal scholarship, see J.M. Balkin, Interdisciplinarity as Colonization, 53 WASH. \& LEE L. REV. 949 (1996); Charles W. Collier, The Use and Abuse of Humanistic Theory in Law: Reexamining the Assumption of Interdisciplinary Legal Scholarship, 41 DUKE L.J. 191 
arship, social identities are oftentimes central, though admittedly always contingent and constructed. ${ }^{72}$ Consequently, this scholarship accepts different perspectives or subjectivities, as well as nontraditional methodologies, including analyses that, influenced by developments in the natural sciences, are aware of the effect of the observer and are sometimes even written in the first person. ${ }^{73}$

Under this model, vanguardist scholars, like mainstream or imperial scholars, oftentimes produce "traditional" law review texts. However, they also produce with regularity unconventional texts that showcase innovative or oppositional methodologies, like "legal storytelling" - a methodology consonant, if not synergistic, with identityconscious analysis. ${ }^{74}$ This embrace of identity and other nontraditional innovations helps to bring to critical, vanguardist texts a heightened awareness of the linguistic and representational elements of legal expression, ${ }^{75}$ an awareness oftentimes bleached completely

(1991). This melding of law with social science nonetheless is still evident and fruitful in the scholarship produced under the rubric of law and society. See infra notes 84-92 and accompanying text (on the law-and-society approach to legal knowledge production). The same efforts continue in Latina/o legal studies. For an example of interdisciplinary LatCrit scholarship, see Mary Romero, Class Struggle and Resistance Against the Transformation of Land Ownership and Usage in Northern New Mexico: The Case of Las Gorras Blancas, 26 CHICANO-LATINo L. REV. 87 (2006).

72 See, e.g., Gary Peller, Race Consciousness, 1990 DuKE L. J. 758 (1990). See also supra notes 54, 66-70 and sources cited therein (on CLS and CRT); infra note 73 and sources cited therein (with references to various works published in CRT anthologies and CLS symposia).

73 For examples of critical race texts, see CRITICAL RACE THEORY: THE KEY Writings That Formed THE MOVEMENT (Kimberlé Crenshaw, Neil Gotanda, Kendall Thomas \& Gary Peller eds., 1995); CRitical RACE Theory: The Cutting Edge (Richard Delgado \& Jean Stefancic eds., 2000); and CRT CROSSROADS, supra note 54. For early examples of this scholarship in law reviews, see Symposium, Excluded Voices: Realities in Law and Law Reform, 42 U. Miami L. ReV. 1 (1987); Symposium, A Forum on Derrick Bell's Civil Rights Chronicles, 34 ST. LOUIS U. L.J. 393 (1990).

For an oft-cited example of critical legal studies and texts, see Symposium, Critical Legal Studies, 36 Stan. L. REV. 1, (1984); see also Symposium, A Symposium of Critical Legal Studies, 34 AM. U. L. REV. 927, (1984); Symposium, Symposium on Critical Legal Studies, 6 CARdozo L. ReV. 691, (1984); Colloquy, Professing Law: A Colloquy on Critical Legal Studies, 31 ST. LouIS U. L.J. 1, (1986); MARK KelMAN, A GUIDE TO CRITICAL LEGAl STUdIES (1987); Symposium, Minority Critiques of the Critical Legal Studies Movement, 22 HARV. C.R.-C.L L. REV. 297 (1987). For a description of critical legal studies from the vantage point of someone who was a close observer of the events and the personalities, see John Henry Schlegel, Notes Toward an Intimate, Opinionated, and Affectionate History of the Conference on Critical Legal Studies, 36 STAN. L. REV. 391(1984).

74 For an analysis of the use of narrative formats in critical theory, see Montoya, Celebrating Racialized Legal Narratives, supra note 54; and for a narrative that chronicles how legal storytelling is being used in a Mexican law school, namely the Autonomus University of Ciudad Juarez, see Margaret E. Montoya, Antígona: A Voice Rebuking Power, 75 U. Mo. KAnSAs CITY L. REV. 1171 (2007).

75 See Margaret E. Montoya, Law and Language(s): Image, Integration, and Innovation, 7 LA RAZA L.J. 147 (1994) (uses Francoise Lionnet's concept of metissage to examine the linguistic hybridity involved in interviewing and counseling the bilingual client within the setting of a 
from the text under the imperial model in the pursuit of reason, logic, objectivity, neutrality, detachment, and the like. ${ }^{76}$ As method, vanguardist scholarship thus makes increased use of "non-legal" sources from diverse media, disciplines, and formats.

More often than not, the critical stance of vanguardist scholarship deploys this expanded tool kit of knowledge-production to expose unjust social realities, structural material inequalities, and psychosocial dysfunctions that afflict society at large and traditionally subordinated communities specifically. In marked contrast with imperial stances, though somewhat reminiscent of Realism's gist, vanguardist scholars acknowledge openly the political nature of legal scholarship in a legalistic society and reject notions of neutrality or objectivity in favor of confessions of inevitable subjectivity, and with it, partiality. ${ }^{77}$ Consequently, this scholarship accepts different perspectives or subjectivities, as well as non-traditional methodologies, including analyses influenced by developments in the natural sciences. This heightened interdisciplinarity, typically coupled to a critical analytical stance, aimed to create new understandings of legal doctrine to help generate substantive legal reform and social justice change; unlike the reforming doctrinal tinkering of traditional scholarship, vanguard scholarship aims for structural transformation of sociological systems. ${ }^{78}$ Despite some similarities, critical scholarship produced under the vanguardist model, therefore, is self-characterized as oppositional to the weight of the imperial model, both in stance and method as well as in objective and ambition. It also differs in the conditions of its production.

Unlike the atomized knowledge-production conditions of mainstream scholarship situated within the core, "elite" institutions of the legal academy, the vanguardist model depended on the construction of alternative fora to incubate oppositional theory sharply critical of the status quo. This need for structural and institutional alternatives led to a search for venues literally and metaphorically "outside" of the mainstream law school environment and its imperial imperatives. This search eventually led to the adoption of the "safe space" concept,

law clinic); Melissa Harrison \& Margaret E. Montoya, Voices /Voces in the Borderlands: A Colloquy on Re/Constructing Identities in Re/Constructed Legal Spaces, 6 COLUM. J. GENDER \& L. 387 (1996) (an interrogation of the re/presentation of clients and the skills involved in speaking on behalf of others by using, inter alia, the case of Frank Baca, a developmentally dis/abled and nonverbal client).

76 See supra notes 31-64 and accompanying text (on the basic or salient attributes of imperial scholarship).

77 For illustrative example, see Harris, supra note 67; Matsuda, supra note 70; Tushnet, supra note 68.

78 See, e.g., Charles R. Lawrence III, Race, Multiculturalism, and the Jurisprudence of Transformation, 47 STAN. L. REV. 819 (1995). 
in which the small cell of similarly situated scholars meeting periodically at various physical locations operated as the principal unit of knowledge-production. ${ }^{79}$

This cadre-based approach featured small groups of like-minded scholars gathering annually (or periodically) for intense discussions in alternative conferences or workshops. ${ }^{80}$ These relatively small "cells" of scholars produced and refined their individual texts in the context of these focused discussions. This practice was designed to forge piercingly critical texts, based in great part on common reading lists, shared vocabularies, and intensive small-group discussion. This model produced fundamental challenges to the status quo capable of withstanding imperial scrutiny on imperial terms.

Yet this focus on text production, while spectacularly successful, was not matched with an equal attention to programmatic continuity or to community building, more generally. While a prolific scholarship continues to be published in the form of these genres, neither of these vanguardist experiments survived as regular programmatic events or sustained structural forms beyond a decade. Nonetheless, as with the Realists of the last century, the substantive and methodological triumphs of these vanguard experiments have become solid-if still controversial-fixtures of the contemporary legal scholarship landscape. ${ }^{81}$

79 See Charles R. Lawrence III, Foreword: Who Are We? And Why Are We Here? Doing Critical Race Theory in Hard Times, in CRT CROssROADS, supra note 54, at xi, xvii (providing an explication of the safe space context).

80 Thus, critical legal studies (CLS) had its "summer camps" and critical race theory (CRT) had its "summer workshops"- each to help incubate the ideas of "critical" theory, and then to help sharpen the edges of particular texts being carefully prepared for eventual publication. Typically, participation in these gatherings was by invitation-only, a practice designed to ensure a truly "safe space" for critical exchanges. In these intensive small-group crucibles, CLS generated its (mostly male and white) constellation of stars, while CRT produced its own (mostly of color) counterpart. In relatively short order, these constellations and vanguards effectively became the points of pivot for the unfolding of these critical and outsider discourses. See Kimberlé Williams Crenshaw, The First Decade: Critical Reflections, or "A Foot in the Closing Door," CRT CROSSROADS, supra note 54, at 9; Stephanie L. Phillips, The Convergence of the Critical Race Theory Workshop with LatCrit Theory: A History, 53 U. MIAMI L. REV. 1247 (1999) (providing accounts of the original series of critical race theory workshops, published in the LatCrit symposia); Valdes, supra note 8 (describing the original critical race theory workshops); Athena D. Mutua, The Rise, Development and Future Directions of Critical Race Theory and Related Scholarship, 84 DENV. U. L. REV. 329 (2006) (outlining a comparative and joint history of RaceCrit and LatCrit experiments).

81 See, e.g., Angela P. Harris, Building Theory, Building Community, 8 SocIAL \& LEGAL STUDIES 313 (1999) (on community building and the vanguardist model of the original critical race theory workshops); LatCrit Oral Histories Project, Roberto Corrada Interview, http://www.latcrit.org (follow "Portfolio of Projects" hyperlink; then follow "Portfolio of Projects ONLINE" hyperlink; then follow "Oral Histories Project" hyperlink) (recounting similar points, and quoting Jerome Culp on the CRT workshops and their discontinuation within a decade of their commencement); see also Randall L. Kennedy, Racial Critiques of Legal Acade- 


\section{The "Democratic" (or "Big Tent") Model}

The third model is perhaps best represented by the examples of the Law and Society Association (LSA) and LatCrit, Inc. We also include the Society of American Law Teachers (SALT) in this third model, recognizing that its mission identifies teaching rather than publishing as its core knowledge-production activity. ${ }^{82}$ Of these three democratic experiments, LatCrit is the youngest; it also is the only one born of color. While all three have seen institutional twists and turns throughout their respective histories-and will continue to do so, no doubt - these two differences, in developmental chronology and demographics of origin, have continuing relevance. ${ }^{83}$

Both LSA and SALT emerged as predominantly white male organizations ${ }^{84}$ and over the years faced internal challenges about their

mia, 102 HARV. L. REV. 1745 (1989) (criticizing the methodologies and texts of critical race and feminist theorists). For responses to Kennedy, see Milner S. Ball, The Legal Academy and Minority Scholars, 103 HARV. L. REV. 1855 (1990); Robin D. Barnes, Race Consciousness: The Thematic Content of Racial Distinctiveness in Critical Race Scholarship, 103 HARV. L. REV. 1864 (1990); Scott Brewer, Introduction: Choosing Sides in the Racial Critiques Debate, 103 HARV. L. REV. 1844 (1990); Richard Delgado, Mindset and Metaphor, 103 HARV. L. REV. 1872 (1990); Leslie G. Espinoza, Masks and Other Disguises: Exposing Legal Academia, 103 HARV. L. REV. 1878 (1990). As Professor Jerome Culp observed about an earlier similar dynamic, "all of us have become children of the realist movement." Jerome McCristal Culp, Jr., Firing Legal Canons and Shooting Blanks: Finding a Neutral Way in the Law, 10 ST. LOUIS U. PUB. L. REV. 185, 188 (1991) (also providing a mapping of legal scholarship at that time). The same, we think, can be said today about the "Crits" and their legacies.

82 Another structure within the legal academy that promotes the development of legal scholarship in an open and democratic fashion is the People of Color Legal Scholarship Conferences (POCs). Currently organized into Mid-Western, Northeastern, Western, and Southeastern/Southwestern regions, the POCs are open to participation by faculty of color and occasionally attended by White faculty with affinity for the purposes of the conferences. In addition, these regional conferences meet jointly on a national basis every five years. These varied POCs have facilitated the production of scholarly writings, especially by untenured faculty or those seeking to enter the academy. However, and unlike the three democratic examples we cite to illustrate this model, the POCs do not identify as a critical or progressive organization. For one conference that is representative of the POC's work, see Northeast People of Color (NEPOC) Legal Scholarship Conference 2008, Education \& the Economy: The Real Lives of People of Color (Sept. 12-14, 2008), http://www.bu.edu/law/nepoc/.

83 Other relevant, institutional differences between LSA or SALT and LatCrit continue to exist. For example, LSA was organized more than thirty years ago compared to LatCrit's twelve years; LSA is a fee-membership organization while LatCrit collects no fees and accepts all comers, affirmatively reaching out to new constituencies including those in Latin America and in related disciplines. LSA has a paid executive staff with four full-time employees while LatCrit is staffed exclusively by overly busy, but enthusiastic, volunteers. SALT also requires a membership fee and, as its activities have diversified, has recently hired an executive director. In 2007, it was awarded a capacity-building grant by the Open Society Institute, which allowed it to add professional staff and expand its social justice agenda. See Society of American Law Teachers, About Us, http://www.saltlaw.org/about-us.

84 An early history of the Law and Society Association identifies Laura Nader as one of the few women involved in the early years of the emerging field. See Garth \& Sterling, supra note 11 , at 446 . 
lack of racial and gender diversity, particularly in their core ranks. ${ }^{85}$ However, organized at about the same time (SALT in 1973 and LSA in 1975), both sought to make non-traditional interventions in the business-as-usual status quo of legal academia. The socio-historical events and ramifications of the 1960s, specifically President Lyndon Johnson's War on Poverty, the Civil Rights movement, and "what was happening in the streets," created both an opening for social science to vie with law as the appropriate expertise to analyze state power and an opportunity for a handful of individuals at four universities to conceive of and establish $\mathrm{LSA}^{86}$ as the academic home for a scholarly field that consisted of "empirical critique of institutional processes based on interdisciplinary study and cross-disciplinary knowledgeproduction. ${ }^{, 77}$ This empirical and interdisciplinary bent, reminiscent of Realism, illustrates the elusive and continuing quest to connect law with society; in the LSA context, it also illustrates the continuing need to place legal knowledge-production at the service of social justice for structurally disadvantaged groups. And akin to the "safe space" aspect of vanguard experiments, other explanations for LSA's founding emphasized the need for collegiality or community-building as knowledge-production-a drawing together of scholars with shared interests, especially those who sought respect for the perspectives of social scientists in legal policy debates, "as well as for the 'facts' (in the positivist sense) that their research produced and that lawyers sometimes expropriated." $"$ In these and other ways, the LSA record illustrates how recent oppositional efforts draw from, and build on, the legacies of preceding jurisprudential formations.

85 By way of disclosure, both of us were involved in a 1994 SALT election that added several people of color to the Board of Governors. Also, one of us (Margaret) served on the LSA Board of Trustees in the class of 2001, chaired the 1999 Graduate Student Workshop (the theme was "Race and the Law" and attracted several young scholars who are now active in LatCrit and LSA), and chaired its Diversity Committee from 2003 to 2005. The other one (Frank) served on the LSA Conference Planning Committee in the mid-1990s. For insights into the role of scholars of color in LSA, see Munger, supra note 32, at 60. For further analysis on the links between LSA and CRT, see Laura E. Gómez, A Tale of Two Genres: On the Real and Ideal Links Between Law and Society and Critical Race Theory, in THE BLACKWELL COMPAnion to LaW AND Society 453 (Austin Sarat ed., 2004). As of 2007, Professor Gómez (UNM) is the President-elect of LSA, which is evidence of the organization's continuing efforts to be inclusive and more representative of communities of color which have historically been shut out of the leadership of academic organizations. It is noteworthy that the American Association of Law Schools (AALS) will be led by Professor Rachel Moran (UC Berkeley), another Latina law professor.

86 See Garth \& Sterling, supra note 11, at 409, 412.

87 See Munger, supra note 32, at 30.

88 Id. at 26-27. Unlike vanguard efforts, however, this approach to community-building did not limit participation in programmatic events to specific invitees or categories of personal identity. See supra notes 80-82 and accompanying text (on vanguardist efforts). 
As the Johnson administration's imbroglio in Vietnam helped spawn the Law \& Society Association, the Nixon adminstration's Watergate debacle was the social context in which SALT was organized by Professor Norman Dorsen and other progressive law professors, who recognized the need to impact public policy while also responding to the teaching opportunities created by the increasing numbers of non-traditional students-of color, women, Vietnam veterans, gays and lesbians, and from low-income families-with innovative law school curricula and pedagogy. ${ }^{89}$ This origin and orientation thereby reflect many of the same legacies and impulses associated with LSA's formation, even as the two differed in other significant ways. Thus, while LSA emphasized social policy and intellectual interdisciplinarity, and SALT emphasized innovative teaching and social justice, both sought to use legal knowledge for democratic social change by linking academic scholarship and activism to policy issues. In their own respective ways, they sought to wedge open the imperial traditions of their day so that alternative actors and approaches could enter the worlds of Law, and of legal knowledge-production; in particular, both were committed to using Law as a tool against such social evils as poverty, low wages, war, and segregation. Like critical legal scholars and critical race theorists (and ourselves), the originators of these two modern-day democratic experiments drew inspiration in varied ways from the legal Realists to challenge the substantive and structural limitations of imperial traditions.

Though LSA and SALT over time have exhibited elements of the other models to varying degrees, we deem them part of this democratic or "big tent" category because their scholarly activities, such as their main conferences, are characterized by marked, conscious, collective departures from imperial traditions-for example, their emphasis on rupturing imperial borders that demarcate law from other disciplines, or teaching from scholarship, or academic life from activist involvements. They approach knowledge-production as more than a matter of intellect, an activity solely of the mind; they instead seek to integrate word with deed, idea with action-law on the books with law in the streets.

These levels and parameters of collaboration generate growth that, in turn, necessarily challenges the cohesion of democratic scholarly communities, a challenge that becomes perennial with time and success. For example, almost ten years ago, LSA President Frank Munger acknowledged that a sense of marginalization had come to some members of the LSA community with the growth in the reach of

89 See SALT's History, http://www.saltlaw.org/salt039s-history. 
the scholarship, in the size of the membership, in the number of disciplines represented, and in the racial and cultural diversity of the scholars within LSA. In response, he encouraged all LSA members to resist breaking into different theoretical or disciplinary camps. ${ }^{90}$ Professor Munger's description of LSA, consistent with our "big tent" metaphor, is even truer today, as LSA has continued its steady growth: "The field has always been a loose and permeable set of networks. The Law and Society Association is the least exclusive of professional associations. The association has no subsections."

SALT and LSA, like LatCrit, go about their non-traditional business by prioritizing, in systematized ways, inter-generational community-building through serious institution building. In these three experiments, building a scholarly community and autonomous institutional structures go hand-in-hand to make democratic knowledge-production self-sustainable and self-correcting on the basis of explicitly stated organizational principles or goals. The original and expanded events of all three democratic experiments are characterized by openness, and a wide participation of differently situated scholars-in various coordinated activities throughout the year-all integral to the production of diverse kinds of individual texts or other work products. ${ }^{92}$

As we have noted, these democratic experiments are fluid and distinct, and vary in terms of origins, demographics, and priorities; but all have created venues of presentation and exchange with flexible contours and low costs of entry. All three have created autonomous institutional structures to plan, conduct, and sponsor numerous projects and publications, each of them affording programmatic opportunities for individual scholars to present and publish papers, or to undertake alternative knowledge-production initiatives featuring collaboration and boundary crossings of various types-disciplinary, methodological, multilingual, etcetera. Despite their fluidities and differences, each of these efforts produced democratic versions of the "safe space" concept early on in their histories-in retrospect, as a starting point for their unfolding activities. Professor Robert Westley describes the LatCrit version in this way:

The idea of LatCrit as a safe space. . . . People who feel alienated within the legal academy or home school environment can come together and form real friendships, real human relation-

\footnotetext{
See Munger supra note 32, at 65.

Id. at 64 .

92 See infra notes 82-110 and accompanying text (elaborating on these common hall-
} marks). 
ships and be supported in things that otherwise they would not. That's meant a lot to me, and it shows in ways that people remain involved year after year ... it's a safe space [for example and] in particular in that you can talk about issues of sexuality. . . . LatCrit has never been seen as so narrow that it only focuses on issues affecting the "Latina/o" community. It is really an open environment but committed to a critical engagement of multiple categories of difference, and so issues of sexuality, issues of class, issues of race, issues of gender, all these things that are hotbutton issues in our society, you can come to LatCrit and you can talk about these things openly and critically ... it's not a safe space in the sense that no one gets criticized. But it's a safe space in that no topic is taboo. ${ }^{93}$

While the democratic examples scramble and synthesize in varied ways differing aspects of the other two models, democratic experiments do not aim or tend to create or "control" the artificial scarcities of professional recognition, intellectual legitimacy, or space in the pages of (elite) academic journals that are necessary specifically to imperial stratification of scholars and scholarship. They aim, instead, to create diverse, programmatic, recurring opportunities for exchange and collaboration on multiple levels so that individual scholars can build alliances and networks as they develop their scholarly agendas and work, collectively, in the service of social justice. These three democratic experiments aim self-consciously to commingle newcomers and veterans as knowledge-producing, community-building, and institution-sustaining actors. Because of these features, we adopt "democratic" as the name of this third model from the work of a longtime LatCrit scholar, Professor Sylvia R. Lazos Vargas, in a text published in the LatCrit IX symposium. ${ }^{94}$

The democratic ("big tent") approach, though practiced differently in different versions, therefore positively embraces difference and diversity across multiple categories, including empirical and tech-

93 See LatCrit Oral Histories Project, www.latcrit.org (follow "Portfolio of Projects" hyperlink; then follow "Portfolio of Projects ONLINE" hyperlink; then follow "Oral Histories Project" hyperlink).

94 See Sylvia R. Lazos Vargas, "Kulturkampf[s]" or "fit[s] of spite”?: Taking the Academic Culture Wars Seriously, 35 SETON HALL L. REV. 1309, 1310-11 (2005) (describing the diversification and concomitant democratization of the legal academy). The data on the American Association of Law Schools (AALS) website show that in 2007-08, 222 law professors self-identified as Latinas/os and, of those, 86 were female. The data for all law faculty, both tenure-stream and non-tenure stream, additionally show a total of 411 women of color in law teaching and a total number of professors of color, including those marking "other" as their preferred identity, equal to 928. AALS, 2006-2007 AALS STATISTICAL REPORT ON LAW FACULTY, http://aals.org. cnchost.com/statistics/0607/0607statistics.pdf. 
nocratic definitions of "scholarship" as a form of knowledgeproduction. Nonetheless, democracy resists imposing fixed or universalized "standards" that have characterized the most traditional and most easily accepted forms of scholarly production in the name of "quality" that, in fact, simply or mostly reflect or reinforce imperial projections of a false meritocracy. Indeed, this linkage of democratic practices with oppositional stances calls for deep, continual, and proactive critical re-assessments of "quality" as constructed in a structurally racist, sexist, and homophobic culture. Given the structural dis/incentives in favor of imperialism, and its cultural hegemony in legal academia, we remind ourselves that many of us-certainly the two of us-work in "home" institutions that are products and instruments of colonization. We employ democratic knowledge-production, and its linkage to oppositional practice in the form of collaborative and individual practices, as an antidote toward imperial drift.

While LSA, SALT, and LatCrit continue to this day with their original annual gathering as their anchor and signature events, all three have created a portfolio of related activities to reinforce and diversify this programmatic anchor. ${ }^{95}$ Perhaps more importantly, all three have used the early collective act of institution-building to create conditions of continuity for the inter-generational production of knowledge in both traditional and non-traditional terms. Professor Mario Barnes has commented about LatCrit's particular approach:

My first LatCrit was the one they said was in Philadelphia but was actually in Malvern, PA. . . . You had to shuttle if you wanted to go to the city. ... You go to conferences and lots of panels are hit or miss, either the subject matter or the performance of panelists. It was so excellent to go to a place where I wanted to go to every panel and where every person who was a speaker did such an amazing job. Secondarily was this whole notion of building in, intentionally, social time in the conference. The whole notion of the hospitality suite, which I had never experienced at any other Law and Society or AALS or other large conference I had gone to. Not just in the social way where I got to meet and talk to so many people whose work that I admire. . . A At Malvern, I met for the first time a person who it turned out was writing on things similar to what I was writing on. In the hospitality suite, we said, 'You know what? We should write together,' and that has been going on since Malvern and we've just completed our second article together and we've al-

95 For detailed information on these three groups or institutions, see their respective websites at http://www.lawandsociety.org, http://www.saltlaw.org, and http://www.latcrit.org. 
ready published our first article. But for LatCrit, it wouldn't have happened. ${ }^{96}$

In particular, all three-LSA, SALT, and LatCrit-have branched out beyond the original annual anchor events to sponsor mentoring programs for junior scholars. ${ }^{97}$ This common emphasis, though carried out in varied ways, over time yields a common attention to the production of diverse scholars as well as diverse scholarship. This community-building helps to create the conditions of knowledge-production for diversely situated individual scholars with a common interest in promoting antisubordination consciousness and action. This combination of proactive institution building and community-building has taken the "safe space" concept beyond the momentary fragments of time and exchange created through a single, small, and closed annual gathering; these democratic experiments, each in their own ways, have expanded the safe "space" into a safe "zone" that ranges across multiple activities throughout the year. The move from "space" to "zone" thus signifies, and helps to create, a broader and deeper location for varied knowledge-production activities-both individuated and collective-throughout the entire span of each year. ${ }^{9}$

These dual commitments to antisubordination, institutionbuilding, and inter-generational community-building as practices integral to knowledge-production in turn place a special premium on long-term planning and continuity of participation. All three versions of the democratic model are therefore characterized both by highly developed planning processes and high levels of continuous, if varying, participation among various categories or generations of schol-

96 See LatCrit Oral Histories Project, www.latcrit.org (follow "Portfolio of Projects" hyperlink; then follow "Portfolio of Projects ONLINE" hyperlink; then follow "Oral Histories Project" hyperlink).

97 In the instance of LatCrit and SALT, for example, the two have combined their efforts to conduct a joint Faculty Development Workshop, which presents events both during the Annual LatCrit Conference each fall as well as during the Annual Meeting of the AALS each spring. Similarly, the LSA sponsors its Graduate Student Workshop, which like that of LatCritSALT, is designed to mentor developing scholars in programmatic ways. In addition, all three conduct a number of programs and projects that create diverse opportunities for "junior" and "senior" scholars to interact, collaborate, and learn from each other. For additional details on these respective groups and efforts, see supra note 96.

98 This safe zone notion creates a bulwark against the pressures of academic employment and the tensions and micro-aggressions associated with life in the hostile environments of elite law schools. Upon receiving the Clyde Ferguson Award from the Minority Groups Law Section of the AALS at the 2008 AALS conference, Professor Angela Harris commented on the hurt and craziness that we are all exposed to, and sometimes contaminated by, in the seductive imperial fog of the competitive, high status, atomized silos called law schools. 
ars. $^{99}$ In the institutional and intellectual histories of these three democratic experiments, we find that longtime veterans, as well as relative newcomers, continually mix and collaborate on the various projects of the respective communities. In the case of the LatCrit community, for example, long-term planning and continuity of participation have been recognized as necessary practices for democratic knowledge-production. $^{100}$ Not (too) surprisingly, therefore, about two-thirds of the authors published in the first LatCrit annual symposium twelve years ago were still present at the Twelfth Annual LatCrit Conference in 2007, while during that time conference participation also expanded from about 65 to nearly 200 participants. This combination of continuity and expansion creates a fluid and rich mix of participants that ensures the vitality, flexibility, and progression of our conversations and programs from year to year.

Although in varied ways, this trio of democratic formations, viz., LSA, SALT and LatCrit, manages the basic business of knowledgeproduction, in our capacities as legal academics, in consciously programmatic terms. This self-aware approach combines vision, collaboration, and interaction to delineate and sustain the trajectory of collective actions as academic activism. Their long-term planning processes, accessibility, continuity of involvement, and collective institution-building are designed to produce, over time, a relatively diverse

99 For an analysis of how university faculties (not including the professional schools) are changing because of the aging and retirement of Left-leaning (although only some $17 \%$ of the older age group would self-describe as "liberal activists"), highly ideological professors who are being replaced by cadres of younger, politically moderate, and ideologically more neutral professors, see Patricia Cohen, The '60s Begin to Fade as Liberal Professors Retire, http://www.nytimes.com/2008/07/03/arts/03camp. html?_r=1\&oref=slogin (last visited July 3, 2008).

100 Since the beginning, as we have already noted, LatCrit theorists have emphasized community-building as an aspect of institution-building under the democratic model. See supra notes 93-99 and accompanying text. More specifically, we have emphasized the importance of long-term planning to discursive progress; we have linked the construction and continuity of community to the progression of knowledge-production. See Valdes, supra note 8, at 1299-1311. Our aim, as we have explained, has not been to ensure that everyone is present at every moment-an unrealistic goal in any event. Instead, our aim has been to ensure a critical mass of veterans to help ensure a mix at every event likely to facilitate continuity and progression of critical inquiry. The idea is simple: at the typical conference, programs sometimes repeat prior advances simply because today's participants may not have been present in yesterday's discussion; by promoting a fluid critical mass at every event, we have tried to ameliorate this all-toofrequent dynamic. Id. at 1305 . In fact, the levels of continuity and diversity-from the mid1990s to the present-attest to the hard work of principled yet open community-building that has become a hallmark of LatCrit theory, and as a means of producing knowledge in democratic rather than imperial or vanguardist terms. The high percentage of continual participation and work in varied capacities a dozen years after inception of this movement honors the long-term original commitments we made to ourselves and this project. Moreover, this level of continuity and diversity compares very positively to the kinds of discontinuity we have seen under imperial or vanguardist models. See supra notes 31-81 and accompanying text (describing these models). 
and democratic "tent" (or "zone") for interactive and multidimensional knowledge-production. From our perspective, these democratic combinations stand in discernible contrast to imperial (or vanguardist) historical examples. It is this common underlying approach that, in our minds, helps to unite these three otherwise distinctive examples of contemporary legal discourses under the democratic model.

In sum, each of these three democratic experiments combine a concern with cases and doctrine, as well as with social-cultural insights that inform our understanding of legal principles or public policies. Generally, they attempt to embrace affirmatively the inclusion of scholars and texts from various disciplines, locations, and perspectives. They also encompass texts that are sharply critical, as well as those that are less so. Each features texts that fit the model of traditional law review articles, as well as those that are reminiscent of nontraditional innovations like legal storytelling. These democratic bodies of scholarship seek to promote, in affirmative ways through programmatic themes, an integration of comparative and internationalist sensibilities in the production of legal scholarship within and without the United States. Yet starkly different racial and ethnic origins, as well as significant and substantial temporal divides, help to explain much that differs among these democratic experiments. Created mostly by white "liberal" males during liberalism's national and political ascendancy, both SALT and LSA pioneers quickly garnered major fiscal support from progressive-minded faculties and foundations; LSA, in particular, timely found a heady audience of official readers ready to apply law-and-society prescriptions to the War on Poverty and other shiny new programs of the activist state that held the reins of power during those decades. ${ }^{101}$ While both LSA and SALT considered themselves as relative "outsiders" in the legal academy, they found receptive listeners and supporters among decisionmakers in mainstream institutions and government agencies (for example, LSA applied for and received grants from the National Science Foundation and SALT submitted both written and oral testimony in connection with Congressional hearings regarding federal judges). On the other hand, LatCrit theory, created mostly by people of color with a decidedly critical bent, emerges with no foundation or mainstream support at hand, and during the height of "backlash" and "retrenchment" - in the very midst of the legal and political "counterrevolution" dedicated to "rolling back the New Deal" and its neces-

101 Austin Sarat \& Susan Silbey, The Pull of the Policy Audience, 10 LAW \& POL'Y 97 (1988) (reviewing law and society scholarship to map its incorporation of realism and focus on policymakers). 
sary intellectual liquidation of crits and criticality from the core or imperial institutions of the legal academy. ${ }^{102}$ Given these dramatic differences in contexts of origin, these three democratic experiments must, and do, differ in marked ways.

Nevertheless, in our view, all three manage the basic business of knowledge-production in consciously programmatic ways designed to produce, over time, a relatively diverse and democratic "tent" or "zone" of oppositional safety. It is this commonality that produces in each an emphasis not only on the immediate or short-term creation of elegant or incisive texts by today's "best and brightest" scholars, but an equal emphasis also on enabling "junior" scholars to develop their talents, skills and networks in the ongoing cultivation of a knowledgeproducing discourse. This dual emphasis, seen most institutionalized in the democratic choices and structures of LSA, SALT and LatCrit theory, helps bring into sharp relief how knowledge-production is a multi-faceted, many splendored thing.

In this brief mapping exercise we have focused on relatively discreet jurisprudential experiments to help illustrate the three main models of knowledge-production that predominate within the legal academy of the United States today. In mapping this landscape, we aim to help situate and explain the LatCrit experiment. Throughout this brief mapping exercise, however, we also have acknowledged that, in operation, the three models oftentimes overlap, interact, or blend. We have noted that individual scholars can draw, and do draw, from different elements or aspects of the three models in their individual texts. We similarly have noted that entire bodies of scholarship can exhibit elements of the three models as well. ${ }^{103}$ This fluidity, characteristic of the three models as we have acknowledged here, is perhaps best illustrated by other diverse strands of critical outsider jurisprudence, which have emerged and developed during the past two decades as well.

102 See, e.g., Hernández-Truyol et al., supra note 67 (providing a historical perspective on the conditions surrounding the emergence of LatCrit scholarship in the mid-1990s). For an early elaboration of this rollback campaign or "counter-revolution" from a mainstream perspective, see Kenneth Karst, Religion, Sex, and Politics: Cultural Counterrevolution in Constitutional Perspective, 24 U.C. DAVIS L. REV. 677 (1991). For similar exposition from a critical outsider perspective, see Kimberlé Williams Crenshaw, Race, Reform, and Retrenchment: Transformation and Legitimation in Antidiscrimination Law, 101 HARV. L. REV. 1331 (1987). For a more recent critical overview of the backlash campaigns in and through law, see Francisco Valdes, Culture, "Kulturkampf" and Beyond: The Antidiscrimination Principle Under the Jurisprudence of Backlash, in THE BLACKWELl COMPANION TO LAW AND SOCIETY 271 (Austin Sarat ed., 2004); see also supra note 10 and sources cited therein (on backlash kulturkampf in law, policy, and society).

103 See supra notes 31-110 and accompanying text (on these points of comparison and detail). 
Critical legal feminisms, queer legal studies, and Asian-American legal scholarship are three examples of distinct outsider legal discourses that exhibit a high degree of mixture, drawing from the three knowledge-production models. Though each of these three discourses has its own distinct histories and contours, all are characterized by a relatively high degree of substantive, structural, and methodological hybridity; all three draw from mainstream traditions, as we all do, and combine different kinds of structures, ideas, and approaches to a degree that effectively eludes any of the three basic models. Thus, it is typical to speak of legal feminisms in the plural precisely because no coalescence around any one particular model has occurred organically within feminist legal scholars and scholarship. ${ }^{104}$ Similarly, queer legal theory is a product of highly decentralized activities, of relatively unstructured and uncoordinated events, featuring aspects of the three different models in varied ways. ${ }^{105}$ Asian-American legal scholarship is likewise produced chiefly through individual compositions vetted through an annual conference and regional meetings of like-minded scholars. $^{106}$ Although centers, institutes, workshops, conferences, and other organizational structures dedicated to feminist, queer, and

104 For a recent overview of legal feminisms, see ANN SCALES, LEGAL FEMINISM: ACtivism, LAWYERING AND LegAL THEORY (2006); see also DEBORAH L. RHOdE, Theoretical Perspectives on SeXual Difference (1990) (providing a similar, earlier overview of legal feminisms). For an early and influential articulation of feminism in legal theory, see CATHERINE A. MACKInNON, FEMINISM UNMODIFIED: Discourses On LifE AND LAW (1987).

105 For an early overview of queer legal theory, see Francisco Valdes, Queers, Sissies, Dykes and Tomboys: Deconstructing the Conflation of "Sex," "Gender" and "Sexual Orientation" in Euro-American Law and Society, 83 CAL. L. REV. 1, 344-375 (1995). For a current, and more nuanced, exposition, see Adam P. Romero, Methodological Descriptions: "Feminist" and "Queer" Legal Theories (unpublished manuscript on file with authors). For a sample of more recent work on the rights of sexual minorities, see Symposium, Out of the Closet and Into the Light: The Legal Issues of Sexual Orientation, XXIV ST. LouIS U. PUB. L. REV. 1 (2005). For a forthcoming example of Queer-Feminist work, see FEMINIST AND QUEER LEGAL THEORY: Intimate Encounters, UnCOMFortable CONVERSATIOns (Martha Fineman, Adam P. Romero, Jack Jackson eds.) (forthcoming 2009).

106 For an early and influential call to Asian American critical legal scholarship, see Robert S. Chang, Toward an Asian American Legal Scholarship: Critical Race Theory, Post-Structuralism, and Narrative Space, 81 CAL. L. REV. 1241 (1993). See also FranK H. Wu, Yellow: RACE IN AMERICA BEYOND BLACK AND WHITE (2002) (situating Asian American legal scholars and scholarship within the particular frameworks of North American discourse and politics on race and ethnicity); Robert S. Chang and Neil Gotanda, Afterword-The Race Question in LatCrit Theory and Asian American Jurisprudence, 7 NEV. L.J. 1012 (2007) (calling attention to the need for greater attentiveness to the role of race and comparative racialization in intergroup relations and within these ongoing bodies of legal scholarship); Sumi Cho, Redeeming Whiteness in the Shadow of Internment: Earl Warren, Brown, and a Theory of Racial Redemption, 40 B.C. L. REV. 73 (1998); Converging Stereotypes in Racialized Sexual Harassment: Where the Model Minority Meets Suzie Wong, 1 J. GENDER, RACE \& Just. 177 (1997); (with G. Chin, J. Kang, and F. Wu), Beyond Self-Interest: Asian Pacific Americans Towards a Community of Justice, 5 UCLA ASIAN PAC. AM. L. J. 129 (1996). 
Asian-American scholarship have sprouted throughout the academy during the past quarter century, these institution-building efforts have not converged or coalesced around any particular model of knowledge-production. Instead, these three bodies of scholarship represent organic and fluid combinations of the three models, which evidently can emphasize at any given time aspects of one or the others depending on the scholar, the situation or other circumstances. ${ }^{107}$ In this way, the Asian, feminist, and queer examples demonstrate how both individuals and bodies of legal scholarship can mix and match the three basic models, or parts of them, in myriad combinations.

Finally, we note, also briefly, that postcolonial legal studies, indigenous legal scholarship, and related discourses have developed their own unique contours, which similarly reflect specific and varying combinations of the three basic models even though they incorporate non-law disciplines more intensively than is usual in legal scholarship generally. ${ }^{108}$ Incubated chiefly in other disciplines, postcolonial studies centered the experiences of societies around the world with the effects of mostly European colonial adventures. Incorporated into legal scholarship during recent years, this centering also helped to deepen and broaden comparativist critiques and transnational investigations of contemporary legal structures and their imperatives, both within and beyond the United States. ${ }^{109}$ Originally, the dominant form of Indian law scholarship focused on federal Indian law-the doctrines and rules developed by federal judges and executive agencies to control the lands, resources, and behavior of Native peoples. ${ }^{110}$ More recently, as Native peoples have been hired and been tenured, they have begun to explore the internal law of tribes and this area of law has come to be known as Indigenous law or the law of Indigenous Peo-

107 Like other bodies of legal scholarship, these examples thus illustrate how the elements of the various models can be, and are, mixed and matched, both in individual texts and in bodies of discourse. See supra notes 104-106 and accompanying text.

108 Consequently, interdisciplinarity is highly salient in these knowledge production efforts. For background readings on postcolonial studies, see generally CONTEMPORARY Postcolonial Theory: A ReAder (Padmin Mongia ed., 1996).

109 For examples of postcolonial studies by scholars associated with LatCrit see Tayyab Mahmud, Migration, Identity, \& the Colonial Encounter, 76 OR. L. REV. 633 (1997); Geography and International Law: Towards a Postcolonial Mapping, 5 SANTA ClARA J. OF INT'L LAW 525 (2007); Ratna Kapur, The Citizen and the Migrant: Postcolonial Anxieties, Law and the Politics of Exclusion/Inclusion, 8 THEORETICAL INQUIRIES L. 537 (2007); Ratna Kapur, The Tragedy of Victimization Rhetoric: Resurrecting the "Native" Subject in International/Post-Colonial Feminist Legal Politics, 15 HARV. HUM. RTS. J. 1, 2 (2002) (describing gender and cultural essentialism within a Third World context).

110 The leading source on federal Indian law is Cohen's HANDBOOK FEDERAL INDIAN LAW (Nell Jessup Newton ed., 2005). 
ples. ${ }^{111}$ Both postcolonial and indigenous approaches to legal knowledge-production, while still in flux, help to further illustrate the rich and thick tapestry that our collective and respective experiments with traditional and nontraditional forms of scholarship have helped to weave during the past quarter century as serious alternatives to mainstream or imperial norms.

North American legal history thus shows that, while there may be many ways and means to produce knowledge through legal discourse, few examples exist involving significant numbers of Latinas/os, either as producers of knowledge or as objects of study. Indeed, as we noted at the outset of this Afterword, this very point was at the heart of LatCrit's origins. Because LatCrit theory has been the single body of contemporary discourses that to date has most attempted to center "Latinas/os" (and our multiple diversities and needs) in legal scholarship-and keeping with the focus of this Symposium-we now turn our attention to that body of scholarship, on its practices, and on those that it opposes.

\section{OUTSIDER DEMOCRACY: A SKETCH OF THE LATCRIT EXPERIMENT}

From its inception, the LatCrit project exhibited a multifaceted focus, as reflected in the four inter-related "functions" or goals of LatCrit work proposed at the very outset of this jurisprudential experiment ${ }^{112}$ - a focus aimed to integrate (1) "theory" with (2) "com-

111 Various scholars have developed this counter-tradition in legal scholarship on indigenous communities. See, e.g., Zuni Cruz, Shadow War Scholarship, supra note 12; see also Christine Zuni Cruz, Toward a Pedagogy and Ethic of Law/Lawyering for Indigenous Peoples, $82 \mathrm{~N}$. D. L. REV. 863 (2006); Four Questions, supra note 51; Tribal Law as Indigenous Social Reality and Separate Consciousness: [Re] Incorporating Customs and Traditions into Tribal Law, 1 TRIBAL L. J. 1 (Jan. 2001); [On the] Road Back In: Community Lawyering in Indigenous Communities, 5 ClinICAL L. REV. 557 (1999), reprinted in 24 AM. INDIAN L. REV. 229 (1999-2000); Strengthening What Remains, 7 KAN. J.L. \& PUB. POL'Y 17 (1997). See also John Borrows, Creating an Indigenous Legal Community, 50 MCGILL L.J. 153 (2005); Foreword- Issues, Individuals, Institutions and Ideas, 1 InDigenOus L. J. vii (2002); Robert B. Porter, Tribal Lawyers as Sovereignty Law Warriors, 6 KAN. J. L. \& PUB. POL'Y 7 (1997); Pursuing the Path of Indigenization in the Era of Emergent International Law Governing the Rights of Indigenous Peoples, 5 Yale Hum. RTs. \& DeV. L. J. 123 (2002); James (Sa' ke' j) Youngblood Henderson, Postcolonial Indigenous Legal Consciousness, 1 Indigenous L.J. 1 (2002); DARLENE JOHNSON, Litigating IDENTity: The CHALlenge OF ABORiginAlity (forthcoming 2008-09); and Patricia Monture-Angus, On Being Homeless: One Aboriginal Woman's “Conquest” of Canadian Universities, 1989-1998, in CRT CROSSROADS, supra note 54, at 274. As these representative sources illustrate, this emergent scholarship incorporates transnational analyses that cross the existing borders demarcating "Canada" from the "United States" in native lands.

112 The four inter-related functions are: (1) the production of knowledge; (2) the advancement of social transformation; (3) the expansion and connection of antisubordination struggles; and (4) the cultivation of community and coalition, both within and beyond the confines of legal academia in the United States. See Valdes, Under Construction, supra note 13; Valdes, Theoriz- 
munity" expressed or performed as (3) "praxis." This conscious integration flowed from a collective recognition that the legal academy of the United States is itself a site of struggle and contestation. It is a site that forms the macro-crucible for the production of legal knowledge in this country, knowledge deployed to tranquilize society into controlled discontent, or to confirm the stirring of social justice consciousness. It is a site for the identification and cultivation of intergenerational leaders trained to serve power, privilege, and hierarchy-or, alternatively, emboldened to bring Law incrementally closer to Justice.

Reflecting the norms of the legal academy, the LatCrit version of the democratic model began with an annual conference designed to bring diverse scholars together in the production of legal knowledge using oppositional ways and means, and specifically oppositional to the traditional or mainstream model. This opposition flowed from a recognition that the traditional and mainstream model oftentimes lent itself more to maintaining hierarchy through careerism and selfpromotion than to the production of knowledge in the service of social justice. ${ }^{113}$ Thus, this initial effort embraced many of the features associated with the vanguardist model, including critical legal studies and, especially, critical race theory. Indeed, as we and other LatCrit scholars have explained for more than a decade, the LatCrit project proceeded most proximately from the vanguardist model of these critical experiments, and with feminism's lessons. ${ }^{114}$ We sought (and seek) to learn from the experiences of scholars, using those mod-

ing "OutCrit" See Valdes, Under Construction, supra note 13; Valdes, Theorizing "OutCrit" Theories, supra note 8 (describing LatCrit origins, principles, purposes, and practices). To review the programs of each LatCrit conference, see www.latcrit.org.

113 For an early, self-critical articulation of this point, published in the LatCrit I symposium, see Sumi K. Cho, Essential Politics, 2 Harv. Latino L. Rev. 433 (1997). For a more recent articulation of similar points and concerns, published in the LatCrit IX symposium, see Aya Gruber, Navigating Diverse Identities: Building Coalitions Through Redistribution of Academic Capital-An Exercise in Praxis, 35 Seton Hall L. ReV. 1201 (2005).

114 See, e.g., Francisco Valdes, Foreword-Poised at the Cusp: LatCrit Theory, Outsider Jurisprudence and Latina/o Self-Empowerment, 2 HARV. LATINO L. REV. 1, 56-59 (1997) (emphasizing LatCrit's close kinship to CRT in particular). This kinship extends equally to Critical Race Feminism, through which women of color have articulated a feminist discourse that, while related to and drawing from traditional feminism, has distinctive themes and is characterized by OutCrit-style linking of issues pivoting the interplay of race, gender, and other identity categories. See, e.g., CRITICAL RACE FEMINISM: A READER (Adrien Katherine Wing ed., 2d ed. 2003); GlobAl CRITICAl RACE FEMINISM: An INTERnAtionAl READER (Adrien Katherine Wing ed., 2000). For a recent collection of works on Critical Race Feminism, see Mary Jo Wiggins, The Future of Intersectionality and Critical Race Feminism, 11 J. CONTEMP. LEGAL IssuES 677 (2001). 
els/methods to help inform the configuration of the "LatCrit" subject position emerging in the early-1990s. ${ }^{115}$

Therefore, in the earliest years, the LatCrit conferences were characterized by a proactive planning committee that sought affirmatively to apply the lessons of the vanguardist model, feminism, and other precursors to this new jurisprudential experiment. To a significant extent, during those early years, the LatCrit conference themes focused on the issues that then were deemed most controversial within vanguardist and/or feminist scholarship, including issues of sameness/difference in knowledge-production contexts. ${ }^{116}$ However, unlike the vanguardist model, these conferences were open to all participants and almost always met in plenary session. ${ }^{117}$ As a result, during the early years we forged specific programmatic techniques, like "rotating centers" and "streams of programming," designed to build on the vanguardist experiments, but on democratic terms, as we have previously explained elsewhere. ${ }^{118}$

Over time, this approach attracted more and more participants, eventually outpacing the capacity of the original conference model to meet always in plenary session: for example, while approximately sixty-five scholars participated in the 1996 LatCrit I conference, this number had tripled, to about two hundred, by LatCrit XII in 2007. Therefore, during the past several years the LatCrit conferences have begun to meet both in plenary and in concurrent sessions. Moreover, the planning committee now limits itself to the planning of specific program "anchors" (including the signature 'theme' panel, the keynote speakers, the Jerome Culp Annual Lecture, and the like) rather than planning in detail the entire program. ${ }^{119}$ In other words, while in

115 See supra notes 9-10 and sources cited therein (on LatCrit origins).

116 See generally Symposium, LatCrit Theory: Naming and Launching a New Discourse of Critical Legal Scholarship, 2 HARV. LATINO L. REV. 1 (1997) (publishing the essays from the First Annual LatCrit Conference).

117 We base this account principally on our personal experience in conference planning, and our participation in these events. However, the conference programs from the past dozen years illustrate the openness and diversity of LatCrit projects. To view the conference programs, including the earliest ones, see www.latcrit.org. On one occasion during the LatCrit I conference the women met alone, and on another occasion, during the LatCrit IV conference, a talking circle involving a group of self-selected participants talked about Indigenous and mestizo identities. Both of these "spontaneous" caucuses help to illustrate the organic and democratic nature of the LatCrit experiment.

118 For an early elaboration, see Valdes, Theorizing "OutCrit" Theories, supra note 8 (presenting the LatCrit III Afterword). For a more recent elaboration, see Hernández-Truyol et al., supra note 67 (presenting the LatCrit X Afterword).

119 This account, again, is based on personal experience. For a summary explanation of these evolutions, see supra note 118 (presenting two symposia Afterwords with historical and conceptual explanations of the LatCrit design). For more information on LatCrit projects, programs, and publications, visit the LatCrit website at www.latcrit.org. 
the early years we thought it important to steer the conference program to focus on areas of controversy, in more recent years we have allowed a more "democratic" approach akin to LSA conferences, wherein many, if not most, of the panels are self-organized by individual scholars, or small groups of them, to create an opportunity for the pursuit of a more particularistic project or agenda and a more pluralistic conference as a whole.

As a result-though not in linear fashion-LatCrit programs have been a catalyst for helping to develop a politically progressive discourse beyond the historically under-examined contours of the "black-white" paradigm. ${ }^{120}$ In a related yet distinct contribution, LatCrit programs also have pushed critical outsider scholars to think and write with greater awareness of international and comparative angles on "domestic" issues, including those of race and other axes of sociolegal identity. ${ }^{121}$ Today, therefore, we discuss the "white-overblack" paradigm - a progression that took several years of concerted programming and discourse development-and we do so in transnational frameworks. Whereas a dozen years ago it was relatively commonplace for outsider and critical discourses to frame issues around simplified domestic binarisms, ${ }^{122}$ today scholars are more attentive to the insights generated in part through these and related contributions. $^{123}$

In these and similar ways - though not always in neat and tidy forms-LatCrit programs and scholars have helped to ensure a pro-

120 For a sampling of works on race and ethnicity published during the first decade of LatCrit symposia, see Hernández-Truyol et al., supra note 67, at 262 n.92. We agree fully with Professor Matsuda that the deconstruction of this paradigm must be informed by an antisubordination sense of politics. See supra note 70.

121 For example, last year the South-North Exchange on Theory, Culture and Law (SNX) was focused on comparative uses of race across the hemisphere to produce subjugation and privilege in structural and material terms. For information on this program, see www.latcrit.org. For a sampling of works on transnationalism and internationalism published during the first decade of LatCrit symposia, see Hernández-Truyol et al., supra note 67, at 265 n.100.

122 See, e.g., Rachel F. Moran, Neither Black Nor White, 2 HaRV. LAtino L. REV. 61 (1997) (analyzing how Latinas/os in the U.S. do not "fit" the binary racial schematics of North America); Juan F. Perea, The Black/White Binary Paradigm of Race: The "Normal Science" of American Racial Thought, 85 CAL. L. REV. 1213 (1997) (mapping and critiquing the pervasiveness of this binarism from a Latina/o perspective). See generally, Chang, supra note 106 (analyzing the binary paradigm from an Asian American perspective). Again, we emphasize our agreement with Professor Matsuda that these (and all) analyses of law and society inevitably generate political consequences, which antisubordination scholarship cannot overlook or neglect if our work is to remain intellectually principled and socially relevant. See supra note 120 (citing Professor Matsuda and noting our agreement).

123 This progression is captured crisply in Professor Mutua's essay for the LatCrit III symposium. See infra note 138. 
gression from antiessentialism ${ }^{124}$ and intersectionality ${ }^{125}$ to a more capacious understanding of all subject positions as multidimensional. ${ }^{126}$ We have helped nudge our collective outsider work beyond the focus on the "bottom" to a recognition that bottoms shift according to context and circumstance. ${ }^{127}$ A dozen years of annual conferences and related events have helped to nurture the direction and progression of critical outsider jurisprudence; these institutional efforts, together with those of the individual scholars whose work we reference here, have helped to continue the vitality of critical outsider jurisprudence in these hard times, and since the deactivation of programmatic vanguardist events in the mid 1990s. ${ }^{128}$

This effort, from inception, also prioritized a continuing search for effective and efficient combinations of theory and action, on personal as well as collective levels. Although the annual conferences and related symposia were the original expression of this enterprise, our tripartite emphasis on theory, community, and praxis, in tandem with the four inter-related functions of OutCrit theorizing noted earlier, ${ }^{129}$ soon yielded a "portfolio" of projects designed to incubate LatCrit theory and inform LatCritical action. These projects and programs are designed as a set of practices that are oppositional to the mainstream traditions of the legal academy, and specifically to the atomized traditions of imperial scholarship. These activities and programs are designed to develop innovative approaches to the production of knowledge from within the legal academy of the United States as well as to contest the entrenchment of interlocking hierarchies within the professoriate inconsistent with antisubordination aspirations. Professor Carmen Gonzalez describes her view of LatCrit as an academic innovation:

My first LatCrit conference is unforgettable. It was in Denver, in the mountains outside of Denver. ... It was after my first year of

124 See Angela P. Harris, Race and Essentialism in Feminist Legal Theory, 42 STAN. L. REV. 581 (1990) (developing the concept of anti-essentialism in the context of legal feminisms).

125 See Kimberlé Crenshaw, Mapping the Margins: Intersectionality, Identity Politics, and Violence against Women of Color, 43 STAN. L. REV. 1241 (1990) (developing the concept of intersectional identities and analyses in the context of violence against women of color).

126 Many scholars have contributed to this conceptual unfolding, from anti-essentialism and intersectionality to multidimensionality, during the past two decades or so. For a review, see Hernández-Truyol et al., supra note 67, at 259 n.85.

127 To bring this theoretical evolution into sharper relief, compare Matsuda, Looking to the Bottom: Critical Legal Studies and Reparations, supra note 70 (on "looking to the bottom"), with Mutua, infra note 138 (on "shifting bottoms").

128 The last of the original CRT annual workshops took place in 1996, at Tulane Law School. See also note 81 (referring to Jerome Culp's observations on this point).

129 See supra note 112 and accompanying text (on the functions of theory). 
teaching. For me it was a community that I never dreamed was possible, what I knew I would need to survive ... what [LatCrit] did for me is it connected me to a group of people who shared some of my own passions and motivations for being in legal academy. It was a broad antisubordination agenda, not one strictly limited to race or strictly limited to gender or only class or only sexual orientation, but an ability to perceive problems in a much more holistic manner. That's what I wanted because it was a place where everyone was welcome regardless of what particular focus their own scholarly projects took. It was that inclusiveness, openness to variety of perspectives that to me was so significant. It created a home for me. ${ }^{130}$

As with the other democratic experiments, the original LatCrit annual conference has since expanded into a "portfolio" of projects designed to broaden and deepen this democratic experiment in self-sustaining terms.

The following chart arrays the ongoing projects, and shows the number of times each project has occurred, as part of the multifaceted approaches to knowledge-production that LatCrit scholars have organized under this democratic model: ${ }^{131}$

130 See LatCrit Oral Histories Project, www.latcrit.org.

131 All of the projects in the LatCrit portfolio are fully described in the LatCrit website at www.latcrit.org. 


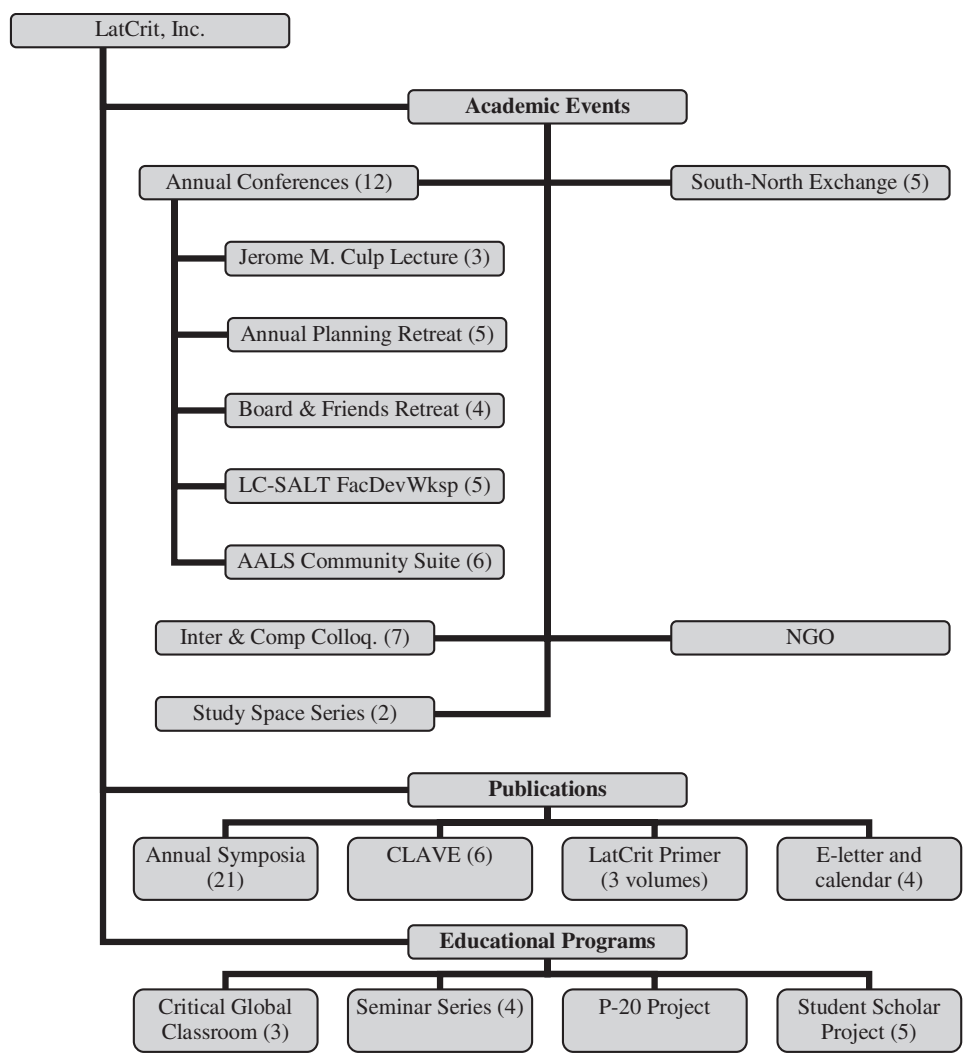

Thus, today the LatCrit Portfolio of Projects, as a whole, is integral to our practice of knowledge-production in democratic, rather than imperial (or vanguardist), terms. This portfolio engages LatCrit scholars in knowledge-production both through traditional means and non-traditional vehicles. This portfolio approaches the basic aims or functions of knowledge-production in the form of various specific initiatives, each with its particular contours and emphases, though all with synergistic connections to the rest, and geared as a whole toward academic activism as social justice action rooted in OutCrit theorizing.

As the chart shows, the LatCrit Portfolio of Projects consistently integrates knowledge-production and academic activism as a core LatCritical practice. As LatCrit theorists have explained, this approach represents a form of "personal collective action" that combines democratic knowledge-production grounded in the antisubordination principle and related practices; in a LatCritical understanding, any attempt to sever these programmatic undertakings from other 
knowledge-production activities amounts to an imperial vivisection of "knowledge-production" as we know and practice it. ${ }^{132}$ From our perspective, this integration is a foundational and indispensable element of LatCrit theorizing regarding democratic knowledge-production in the service of antisubordination consciousness and action.

Our democratic approaches and antisubordination aims necessarily affect even the more traditional aspects or activities that we undertake as legal academics. For example, from inception LatCrit pioneers made a firm commitment to the publication of the proceedings of the annual conferences and, later, of the smaller conferences that now also take place regularly as part of our Portfolio of Projects. ${ }^{133}$ Recognizing fully that law review symposia historically have been structured in various ways in light of different circumstances or objectives-and that sometimes they foster a "community of meaning" while other times they amount to a "re-inscription of hierarchy" ${ }^{134}$ LatCrit scholars opted decisively, from the beginning, in favor of the former.

From the outset, and as this very symposium helps to illustrate, the specific symposium structure created for this scholarly experiment was designed consciously (if imperfectly) to promote democratic values of access and participation, to encourage experimentation with formats, bibliographic sources, multilinguality, and forms of expression, as well as to expand the dissemination of knowledge produced or presented during the conference programs, or "inspired" 135 by them. We have worked consistently not only to foster communities of meaning through these symposia, but also have worked affirmatively to avoid re-inscription of any hierarchies. Thus, in pursuit of those threshold decisions, by choice and on principle, we have opted, from inception, to work with alternative law journals devoted to issues of difference (for example, race, ethnicity, gender, and other axes of identity used in law, policy, and society to generate both privilege and oppression). As with the shift from videotaping to pre-written texts that we discuss below, the growth of our annual conferences (and

132 See Hernández-Truyol et al., supra note 67 (explaining the LatCrit experiment). A brief description of the types of symposia published by LatCrit scholars during the past dozen years is helpful. See infra note 140.

133 To accommodate the growth in conference participation, and to construct the yearround "zone" of activities we discussed earlier, see supra notes 130-31 and accompanying text, LatCrit scholars have conducted numerous smaller workshops, colloquia, and similar events around the world. For examples, please visit the LatCrit website at www.latcrit.org.

134 See generally Jean Stefancic, The Law Review Symposium Issue: Community of Meaning or Re-Inscription of Hierarchy?, 63 U. COLO. L. REV. 651 (1992).

135 We quote the term from the LatCrit Symposium Submission Guidelines, posted at www.latcrit.org. 
other academic programs) led us to work with mainstream journals as well, but our original and continuing commitment to work with alternative journals as a matter of praxis remains an important marker of our collective choices in favor of a democratic intellectual identity. ${ }^{136}$ Rather than pursue the individuated status-generating approaches of traditional or mainstream scholarship, we have chosen consistently to honor the values and principles that bind us together as a community and jurisprudential movement: a focus on the view from the "shifting bottoms." ${ }^{137}$

To begin this early knowledge-producing activity, in the early years, LatCrit theorists videotaped the proceedings of the annual conferences, transcribing them later and forwarding them to the various presenters for refinement and return. These "oral essays," representing a collective search to expand the forms of legal expression and the subjects considered worthy of legal analysis, were then included in the law review symposium reflecting the conference program. As the conferences grew in popularity and size, we had to abandon this original practice in favor of texts composed by the authors before or after the conference in order to publish them-but still in the consciously non-traditional form of a short "oral" essay, as the Symposium Submission Guidelines had stipulated from the very beginning. ${ }^{138}$ Perhaps, then, the twenty-some LatCrit symposia/colloquia published during the past twelve years are best viewed as akin to book anthologies in which the law review volume itself is the book and the short oral essays function as chapters written by individual authors. ${ }^{139}$

136 See Valdes, Theorizing "OutCrit" Theories, supra note 8, at 1305 ("This feature of the LatCrit enterprise seeks to support, and build coalition with, law reviews (especially those of color) while also creating collective projects and opportunities for all participants in LatCrit programs.").

137 Athena D. Mutua, Shifting Bottoms and Rotating Centers: Reflections on LatCrit III and the Black/White Paradigm, 53 U. MIAMI L. REV. 1177 (1999). While we maintain a commitment to the notion, first proposed by Professor Mari Matsuda, that subordination can best be understood if we take the perspective of the person who is "on the bottom," Professor Mutua contributed the corollary that the group at the "bottom" is neither stationary nor static but rather changing depending on the issue, location, time period, etcetera. See Matsuda, supra note 70. As above, we base this account on our personal experiences.

138 Again we quote directly from the LatCrit Symposium Submission Guidelines, posted at www.latcrit.org. The Symposium Submission Guidelines stipulate that conference-based essays should be short and lightly footnoted, and expressly invoke the notion of an "oral essay" as an effort to minimize resort to law-review styles associated with imperial traditions of production. To review the Submission Guidelines, see www.latcrit.org. For further elaboration of the symposium organizational process, see Hernández-Truyol et al., supra note 67.

139 These twenty-some symposia (including the LatCrit XIII conference papers) have been published both in mainstream journals as well as in specialty journals devoted to difference and social justice. See Colloquium, Representing Latina/o Communities: Critical Race Theory and Praxis, 9 LA RAZA L.J. 1 (1996) (publishing the papers of the pre-LatCrit colloquium, held in 1995 in San Juan, Puerto Rico, at which the "LatCrit" name was conceived); Symposium, Lat- 
Crit Theory: Naming and Launching a New Discourse of Critical Legal Scholarship, 2 HARV. LATINo L. REV. 1 (1997) (LatCrit I); Colloquium, International Law, Human Rights and LatCrit Theory, 28 U. MIAMI INTER-AM. L. REV. 177 (1997) (publishing the proceedings of the first LatCrit colloquium focused on international law); Symposium, Difference, Solidarity and Law: Building Latina/o Communities Through LatCrit Theory, 19 CHICANO-LATINO L. REV. 1 (1998) (LatCrit II); Symposium, Comparative Latinas/os: Identity, Law and Policy in LatCrit Theory, 53 U. Miami L. ReV. 575 (1999) (LatCrit III); Symposium, Rotating Centers, Expanding Frontiers: LatCrit Theory and Marginal Intersections, 33 U.C. DAVIS L. REV. 751 (2000) (LatCrit IV); Colloquium, Spain, The Americas and Latino/as: International and Comparative Law in Triangular Perspective, 9 U. MIAMI INT'L. \& COMP. L. REV. 1 (2001) (publishing the proceedings of the second and third International and Comparative Law Colloquia (ICC), held during 1998 and 1999 in Malaga, Spain); Symposium, Class in LatCrit: Theory and Praxis in a World of Economic Inequality, 78 DENV. U. L. REV. 467 (2001) (LatCrit V); Symposium, Latinas/os and the Americas: Centering North-South Frameworks in LatCrit Theory, 55 FLA. L. REV. 1 (2003), 54 Rutgers L. ReV. 803 (2002) (LatCrit VI); Symposium, Coalitional Theory and Praxis: Social Justice Movements and LatCrit Community, 13 BERKELEY LA RAZA L.J. 113 (2002), 81 OR. L. REV. 587 (2002) (LatCrit VII); Symposium, International and Comparative Law in LatCrit Theory: Perspectives from the South, 38 REV. JUR. U. INTER-AM. P.R. 7 (2003) (publishing the Spanish language papers from the 2003 ICC in Buenos Aires, Argentina); Symposium, City and the Citizen: Operations of Power, Strategies of Resistance, 52 CLEVE. ST. L. REV. 1 (2005) (LatCrit VIII); Symposium, Law, Culture, and Society: LatCrit Theory and Transdisciplinary Approaches, 16 FLA. J. INT'L L. 539 (2004) (publishing the papers of the first South-North Exchange (SNX), held during 2003 in San Juan, and the fifth ICC, held that same year in Buenos Aires); Symposium, Countering Kulturkampf Politics Through Critique and Justice Pedagogy, 50 VILL. L. REV. 749 (2005), 35 Seton Hall L. Rev. 1155 (2005) (LatCrit IX); Symposium, Law, Culture and Indigenous People: Comparative and Critical Perspectives, 17 FLA. J. INT'L L. 449 (2005) (publishing the papers of the second and third SNXs, held during 2004 and 2005, in San Juan); Symposium, Constitutionalism and the Global South: Mapping the Politics of Law, 14 GRIFFITH L. REV. 2 (2005) (publishing the papers of the sixth ICC, held during 2004 in Capetown, South Africa and the third SNX, held in San Juan); Symposium, LatCrit Theory: Critical Approaches to Economic In/Justice, 26 UCLA CHICANO-LATINO L. REV. 1 (2006), 17 BERKELEY LA RAZA L.J. 1 (2006) (LatCrit X); Symposium, Free Market Fundamentalism: A Critical Review of Dogmas and Consequences, 5 SEATTLE J. SOC. JUST. 497 (2007) (publishing the papers of the fourth SNX, held in 2006 in Bogotá, Colombia); Symposium, Race \& Color Across the Americas: Comparative Constructions of Racial and Ethnic Subjugation, ___ NAT'L BLACK L.J.__ (20__) (publishing the papers of the fifth SNX, held in 2007 in Rio de Janeiro, Brazil); Symposium, Working and Living in the Global Playground: Frontstage and Backstage, 7 NV. L.J. 685 (2007) (LatCrit XI); Symposium, Critical Localities: Epistemic Communities, Rooted Cosmopolitans and Knowledge Processes, 3 FIU L. REV. 289 (2008) and __ ST. ThOMAS L. REV. __ (20__) (LatCrit XII); Symposium, Representation and Republican Governance: Critical Interrogation of Election Systems and the Exercise of the Franchise, __ SEATTLE U. L. REV __ (20__) (LatCrit XIII); Study Space Panama-Symposium, Entering the $21^{s t}$ Century: Challenges and Opportunities of Panama's Explosive Urban Growth, 4 TENN. J. LAw \& POL'Y 167 (2008) (Studio Space I); Study Space Bogota- Symposium, Multicultural Colombia: Urban \& Rural Lands, Rights of Self-Governance and Cultural Difference, __ U. MiAmi INTER-AM. L. REV.__ (20__) (Study Space II). In addition to these program-based publications, LatCrit scholars have produced two other stand-alone symposia, each published jointly by two journals collaborating on the same texts. See Joint Symposium, LatCrit: Latinas/os and the Law, 85 CAL. L. REV. 1087 (1997), 10 LA RAZA L.J. 1 (1998); Joint Symposium, Culture, Language, Sexuality and Law: LatCrit Theory and the Construction of the Nation, 5 MICH. J. RACE \& L. 787 (2000), 33 U. MICH. J. L. REFORM 203 (2000). Information on LatCrit theory, including the full text of most of the LatCrit symposia based on our Annual Conferences or other academic events (such as the International and Comparative Colloquia and the South-North Exchanges) can be obtained at the LatCrit website, http://www.latcrit.org. 
More importantly, the annual LatCrit symposia exist in direct and self-conscious relation to a specific conference experience. The LatCrit symposia typically are understood and meant to memorialize the proceedings of the annual conference or one of our smaller academic events. Think of them-and their contents-as conference group snapshots presented in the form of these book-like anthologies published in law reviews. To expose patterns, similarities, and differences among presentations, these short essays usually are organized into thematic "clusters." These symposia "clusters" similarly are introduced by a short text, typically authored by relatively veteran scholars, ${ }^{140}$ that is supposed to discuss or situate the essays composing that cluster in the context of the conference theme or program, or of the LatCrit body of literature as a whole. Through this kind of "service scholarship," established scholars endeavor to create a framing wherein the individual texts of particular (and oftentimes relatively "junior") scholars can be viewed as part of an interconnected whole, or an interconnected discourse, rather than the oftentimes unconnected texts written in the context of atomized, imperial scholarship that nonetheless passes as open exchange and engaged discourse. ${ }^{141}$

Not surprisingly, a number of LatCrit scholars have used these programmatic opportunities for presentation and publication to nurse along long-term research agendas yielding multiple and different publications (essays, articles, books). This basic methodology, over the years, has enabled a number of LatCrit scholars to build their careers and develop their overarching research agendas in incremental yet systematic ways. Generally, these scholars have employed the conferences and the LatCrit symposia to publish short segments of larger works, which later in time appear in book form. ${ }^{142}$ knowledge-

140 Rather than reflect a sense of internal hierarchy within the LatCrit scholarly community, this arrangement reflects the diversities and levels of time and experience in this community. See supra notes 133-38 and the accompanying text. The idea of this practice is to bring to bear the knowledge of more experienced scholars to help elucidate the inter-connections between the essays of a cluster in the form of these brief introductions.

141 Veteran scholars also author the Foreword and Afterword, which typically book-end LatCrit symposia. Each of these texts is devoted to different yet complementary functions within the symposium as a whole. The varying functions of the cluster Introductions, Forewords, and Afterwords are spelled out in the Symposium Composition Guidelines, published in the LatCrit Informational CD and on the LatCrit website, www.latcrit.org.

142 Among these, we might include Professors Steven Bender, Pedro Malavet, and Ediberto Román, each of whom began their academic careers in the context of the LatCrit conferences, published regularly short essays in the LatCrit symposia, successfully navigated through the scholarship evaluations connected with faculty tenure procedures at their respective institutions, and eventually produced books on that basis. Some of these works were thus quite traditional; others less so. In our LatCritical view, however, each of the inter-connected work-product that Professors Bender, Malavet, and Román published at the various stages of their multi-year 
productionAs the conferences grew in popularity and number, so did the contributions to the law review symposia publishing the proceedings of each conference. Therefore, in keeping with the LatCrit commitment to antisubordination goals and democratic practices, veteran (and sometimes more established) LatCrit scholars further agreed, on principle, to yield program slots in the conferences, as well as essay slots in the symposia, in order to ensure that "junior" or developing scholars were featured both in the live events, and in the published works memorializing them. In addition, we agreed to limit the substantive participation of each individual to a single slot or presentation in the formal program schedule. These and similar LatCritical choices were designed to check any tendency toward elitism-or the creation of a "star system"- - within our projects and community.

efforts has a legitimate place in the universe of knowledge production, especially under a democratic regime.

Professor Bender's published texts in the LatCrit symposia include: Steven W. Bender, Direct Democracy and Distrust: The Relationship between Language Law Rhetoric and the Language Vigilantism Experience, 2 HARV. LATINO L. REV. 145 (1997); Steven W. Bender, Silencing Culture And Culturing Silence: A Comparative Experience Of Centrifugal Forces in the Ethnic Studies Curriculum, 5 Mich. J. RACE \& L. 913 (2000), 33 U. Mich. J. L. REFORM 329 (2000); Steven W. Bender, Will the Wolf Survive?: Latino/a Pop Music in the Cultural Mainstream, 78 DenV. U.L. ReV. 719 (2001); Steven W. Bender, Sight, Sound, and Stereotype: The War on Terrorism and Its Consequences for Latinas/os, 81 OR. L. REV. 1153 (2002); Steven W. Bender \& Keith Aoki, Seekin' the Cause: Social Justice Movements and LatCrit Community, 81 OR. L. REV. 595 (2002).

Professor Malavet's include: Pedro A. Malavet, Literature and the Arts as Antisubordination Praxis: LatCrit Theory and Cultural Production: The Confessions of an Accidental Crit, 33 U.C. Davis L. ReV. 1293 (2000); Pedro A. Malavet, The Accidental Crit II: Culture and the Looking Glass of Exile, 78 DENV. U.L. REV. 753 (2001); Pedro A. Malavet, Reparations Theory and Postcolonial Puerto Rico: Some Preliminary Thoughts, 13 BERKELEY LA RAZA L.J. 387 (2002); Pedro A. Malavet, LatCritical Encounters with Culture, in North-South Frameworks, 55 FLA. L. REV. 1 (2003); Pedro A. Malavet, Outsider Citizenships and Multidimensional Borders: The Power and Danger of Not Belonging, 52 CLEV. ST. L. REV. 321 (2005).

Professor Román's include: Ediberto Román, Common Ground: Perspectives on LatinoLatina Diversity, 2 HaRv. LAtino L. REV. 483 (1997); Ediberto Román, Reconstructing SelfDetermination: The Role of Critical Theory in the Positivist International Law Paradigm, 53 U. Miami L. REV. 943 (1999); Ediberto Román, A Race Approach to International Law (RAIL): Is There a Need for Yet Another Critique of International Law?, 33 U.C. DAVIS L. REV. 1519 (2000); Ediberto Román, Members and Outsiders: An Examination of the Models of United States Citizenship As Well As Questions Concerning European Union Citizenship, 9 U. MIAMI INT'L \& COMP. L. REV. 81 (2000-2001); Ediberto Román, LatCrit VI, Outsider Jurisprudence and Looking Beyond Imagined Borders, 54 RUTGERS L. REV. 1155 (2002); Ediberto Román, Reparations and the Colonial Dilemma: The Insurmountable Hurdles and Yet Transformative Benefits, 13 BERKELEY LA RAZA L.J. 369 (2002); Ediberto Román, Immigration and the Allure of Inclusion, 35 Seton Hall L. ReV. 1349 (2005). Their books include: STEVEN W. Bender, GREASERS AND GRINGOS: LATINOS, LAW, AND THE AMERICAN IMAGINATION (2003); PEDRO A. Malavet, AmericA's Colony: The Political and Cultural Conflict Between the United States AND PUERTo Rico (2004); Ediberto Román, THE Other AMERICAN COLONIES: AN INTERNATIONAL AND CONSTITUTIONAL LAW EXAMINATION OF THE UNITED

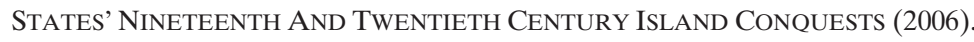


This collective decision of "senior" scholars to yield space and voice within LatCrit conferences and symposia to accommodate developing scholars also reflects the commitment to inter-generational community-building; it represents the aim of establishing a selfsustaining democratic structure for the incubation of antisubordination knowledge and action. During the past dozen years, this practice in the allocation of space in the knowledge-producing activities of the LatCrit community has cultivated layers of scholars with diverse intellectual agendas and personal backgrounds who are commonly committed to the promotion of social justice in multidimensional terms. ${ }^{143}$ This cultivation of understanding and solidarity helps to create a sturdy support structure for the production of scholarship not only throughout the academic year, but perhaps also throughout a lifetime and through changing life circumstances, in ways that transcend the isolated dots of time represented by typical conferences and other similar academic events. Professor Hugo Rojas, a Chilean legal scholar, describes the LatCrit environment thusly:

In 2001 I was working on my thesis about multiculturalism here in the United States . . . and a friend told me I should get in touch with LatCrit because my thesis was about antiessentialism, about creating inclusion and legal recognition of diversity in South America was very connected to legal theories and frameworks here in the States. I was invited and attended LatCrit VI . . . . I love the transparency of the group, the inclusion in all the discussions and the generosity of the contributions.

In every LatCrit conference or workshop, I feel I can really say what I feel and I understand that the opinions I receive are constructive and not destructive. There is no competition. No one wants to be a star . . . in LatCrit you make alliances and it is an open invitation to feel a member of the group [which is] interdisciplinary ... ${ }^{144}$

Through self-reflection and critique, the LatCrit community works incrementally to refine these practices in order to advance, as best as we can, our common and basic commitment to antisubordination in multidimensional terms. This process of self-reflection and critique does not yield linear progress, nor tidy solutions that satisfy our aspirations. Yet this practice-with its emphasis on programmatic

143 We think (and hope) the selected quotations from the LatCrit Oral Histories Project that appear throughout this Afterword illustrate this point vividly. The interviews were conducted by Professor Tayyab Mahmud on October 5-7, 2007. To review the LatCrit XII Oral Histories Interviews in their entirety, see www.latcrit.org.

144 See LatCrit Oral Histories Project, www.latcrit.org. 
opportunities for junior scholars to develop and mature-today represents an oppositional or "dissenting" LatCrit norm, which is key to the creation of a vibrant and self-sustaining democratic academic society within the still-mostly-imperial structures and biases of the legal academy of the United States.

To the undiscerning eye, the LatCrit experiment-and other democratic efforts-may appear to be "messy" when compared to the relatively familiar or controlled practices of the imperial or the vanguardist models. Rather, democratic unruliness is a reflection of the open intellectual society that the LatCrit community has sought to bring into existence. Professor Catherine Smith expresses what is different about the LatCrit conference experience:

...other conferences can be isolating, ... there's not an automatic kinship like I feel there is at LatCrit . . . the conference itselfwhat's being offered, what's being discussed... is so different than any other conference .... Y You don't have to have this long drawn out explanation about where you are coming from. People are there with you. You start from a platform for the discussion at an entirely different level, a really different level....You can extend the dialogue in a way you can't do otherwise. ${ }^{145}$

To us, the apparent messiness of outsider democracy is a sign of vitality and vigor rather than a defect to be quashed. This apparent unruliness is a reflection of the fact that the democratic model tends to generate a more substantively diverse body of discourse even though-or perhaps because-the programmatic structures employed tend to be more institutionalized to foster the personal and intellectual engagement of difference than under either of the two other models. This multidimensional diversity should not be mistaken for inadvertent disarray.

On the contrary, this proactive engagement of difference in multiple ways across multiple axes of identification produces not only knowledge, but also solidarity in the service of social justice action. ${ }^{146}$ These multiple forms and levels of engagement tend to cultivate the openness, understanding, and motivation necessary for antisubordination collaboration across multiple categories of identity-including across intra-"Latina/o" axes of difference; this attention to difference and diversity helps to set the stage for critical coalitions that stand on shared and enduring principles rather than temporarily converging

145 Id.

146 Once again, we think and hope the Oral Histories quotations illustrate this point amply. See supra note 29 and accompanying text (describing the Oral Histories Project). 
interests. $^{147}$ In our experience, the act and process of collaboration over time deepens levels of mutual understanding and trust that progressively enable greater intellectual and discursive risks, which oftentimes yield important epiphanies, and create bonds of mutual respect and engagement that can only enrich any kind of knowledgeproduction activity, both in the short and long term. We recall, borrowing from our feminist jurisprudential ancestry, that valuable LatCrit knowledge-production occurs at multiple levels, including at micro- and meta-levels, as we learn to notice and alter how power, including academic power, reproduces itself in the most quotidian and habitual details of our work.

This facilitation of community and coalition-building based on the production of shared knowledge, experience, action , and understanding - and a mutual recognition of our humanity-is a key feature of the LatCrit experiment, which, in our view, lends itself to the development of Latina/o legal studies as a vehicle for social justice action and transformation. The programmatic and substantive emphases on these kinds and levels of engagement thus lend themselves to the broader project of making multiply diverse "Latinas/os" not only a relevant but also a positive force on the inter/national stages of politics and policy. For these reasons, we offer the methods and lessons of the LatCrit community in democratic knowledge-production and legal academic activism as a microcosm of the opportunities and possibilities present in the emergence of "Latinas/os" as a force to be reckoned with in North American society (and beyond). While we recognize that no approach is perfect, we hope our exertions offer helpful lessons to the coming generation/s of scholars who will continue to work on situating multiply diverse Latinas/os in contemporary legal discourses.

Democratic scholars of different stripes would attest that this project is not easy. But we, at least, think the past dozen years shows it also is clearly worth it. And for this reason, we think it also the best bet for fashioning a capacious and rigorous future for Latina/o legal studies in and beyond the United States in light of the structural realities of systemic subordination that encase us: for a minoritized, marginalized social group, neither imperialism nor vanguardism can light the path toward liberation. For a minoritized and marginalized set of social groups, coalitional theory and collaborative action provide the most promising path to a postsubordination society because they are

147 See supra note 22 and accompanying text (discussing interest convergence and traditional kinds of coalitions). On the other hand, "critical coalitions" signify an alliance based on shared substantive principles and goals. See Julie A. Su \& Eric K. Yamamoto, Critical Coalitions: Theory and Praxis, in CRT CROSSROADS, supra note 54, at 379. 
most geared to the establishment of principled relations of solidarity capable of challenging majoritarian control of law and society. Narrow nationalisms and regressive chauvinisms, on the other hand, promise more of the same neocolonial politics that help to maintain the legacies of white supremacy, and related systems of accumulated privilege, in place. Thus, while all three models may have something to offer in the struggle for intellectual decolonization and material transformation, the democratic model, in our experience, is best suited among the three main models of contemporary legal discourses for knowledge-production in support of antisubordination insurrections against entrenched majoritarian forces.

In sum, the bedrock commitment to synergizing theory, community, and action grounded in the antisubordination principle and democratic practice may confuse scholars who mistake the imperial (or vanguardist) model as the best-or the one "true"-approach to scholarly production. In our view, a reductionist move to delegitimatize democratic approaches to scholarly production simply misses the entire point of the LatCrit enterprise and other democratic experiments - as well as much of the substantive, theoretical knowledge produced in the form of critical outsider jurisprudence-during the past two decades. This reductionism replicates existing patterns of social and intellectual stratification, and thereby risks losing the potential for social justice change of a growing Latina/o influence in North American law and society. Reductionist moves conflate knowledge-production with written texts, and further constrict written texts into the rigid, ossified traditional form of the long, imperial law review article. In our view, this reification is inconsistent with intellectual democracy, much less social justice action and change.

In our view, legal scholars need not and should not be pushed into an either-or situation, blind to the strengths and weaknesses of different approaches to knowledge producing. Instead, as we noted at the outset of this Afterword, history teaches that many ways and means exist for the production of legal knowledge, including in the specific form of contemporary discourse. As the conceptual and operational charts in the Appendix to this Afterword help to illustrate, the combined options available from all three models permit creative approaches tailored to varied knowledge-production aims and contexts. Thus, in our view, none of the basic extant models should reign absolute; scholars should be free to draw from each, depending on circumstances and goals.

Moreover, recalling that symposia historically have been used for different purposes and presented in different formats, we see no reason to insist on homogenizing this particular kind of knowledgeproduction activity into a single format or model now, much less one 
that privileges and perpetuates the near-hegemony of the imperial tradition-that is, a format that serves to re-inscribe traditional or neocolonial hierarchies. While we think that jurisprudential history clearly shows that democratic approaches are most compatible with social justice aspirations, we recognize the continuing relevance of the Stefancic study: that different symposium formats, like the knowledge-production models themselves, may indeed offer utility in particular moments or contexts, and that we should make and keep ourselves critically cognizant of the consequences that attach to the choices we make-in her terms, are we building communities of meaning, or re-inscribing oppressive hierarchies? ${ }^{148}$ No matter how contemporary scholars may choose to mix and match aspects of each format or model in any particular situation, our hope would be that they-we-proceed always with social justice principles and aspirations uppermost in mind and deed.

\section{CONCLUSION}

For more than a decade now, and as a matter of principled and informed choice, the LatCrit community has not-and today still does not-aspire to imperial ambitions, nor subscribe to imperial assumptions. On the contrary, we have continuously and consistently rejected them in our ongoing efforts to construct Latina/o legal studies in robust and variegated democratic terms. As the charts in the Appendix to this Afterword illustrate, we have mixed and matched elements from preceding jurisprudential experiences to craft our own conception of outsider democracy. As we have explained here as well as before, our individual and collective methodological choices are fully conscious even if imperfect.

To secure social transformation, knowledge-production must help to create the conditions of mobilization against the grinding hegemony of the status quo. Social groups and interests characterized by centuries of subordination, disempowerment, and exploitation always face a difficult struggle for equity and dignity. When these disadvantaged social groups additionally are decisively outnumbered, as Latinas/os are within the United States, the linkage of knowledgeproduction with coalition-building becomes correspondingly more crucial-not to mention the fact that "different" systems of sociolegal subordination are overlapping, interlocking, and mutually reinforcing. In our view, the experiences with imperial and vanguardist approaches to legal discourse and knowledge-production strongly indi-

148 See Stefancic, supra note 134. 
cates that neither model is particularly promising in promoting the values of collaboration and coalition so necessary to the stated goal of society's material transformation.

While we have acknowledged that our OutCrit experiment is always under construction, we also have emphasized our continuing efforts to improve and nourish critical outsider jurisprudence along the lines of the democratic model. Among critical and outsider experiments to date, we think the still-young record of the LatCrit community, while very much in progress, has much to offer any project aiming to prioritize antisubordination knowledge in the service of social justice activism. The LatCrit record may not be everything to everyone, but it represents a creative and sustained effort among a diverse group of individuals to rise above self interest in the promotion of social justice through critical theory and academic activism.

And while we are deliberate about acknowledging and, yes, celebrating this space that we denominate as LatCrit, an intellectual location or position that is at once literary, cognitive, virtual, affiliative, and associational, we remain always acutely aware of its limitations and, indeed, its failures. We remain acutely and constantly aware of the fragile and limited nature of our personal and programmatic exertions, and of the imperfect results they produce. We understand that our gains can unravel easily, especially in these times of traditionalist backlash. We know that our choices and labors are no panacea for the ills of law, policy and society that we inherit, and despite our best antisubordination intentions. LatCrit, we know full well, is not the last word on legal knowledge production or academic activism in the service of social justice.

We thus can and do recognize that we have not been effective in fundamentally altering the abrasive conditions within many or most law schools, much less legal culture writ large. Nor, we recognize, have we managed to remake in any dramatic fashion the boundaries of what imperial gazers still prefer as legal scholarship. However, we have managed to create an island of creative academic work that unpacks, challenges, and rages against the mechanisms of illegitimate domination and its disgraceful manifestations in the lives of communities that have little power, resources, or agency-no mean feat. In this still-rebellious spirit, we will continue elsewhere with this critical and self-critical analysis of our fledgling OutCrit experiment in the context of imperial hegemony, adding detail and searching for ways to disseminate this and other efforts to center multi-diverse Latinas/os within contemporary legal discourse. We hope to do so in mutual and respectful solidarity with scholars and activists of all stripes, even those with whom we might disagree, perhaps vehemently, on one or another particular. 
Consequently, we do not quarrel with the proposition that antisubordination knowledge can and should be pursued along multiple lines or methodologies. We do not quarrel with the related proposition that antisubordination knowledge and action may be served in different ways and times by the selective deployment of different aspects of each model. And we certainly do not quarrel with any suggestion that the LatCrit experiment could be improved in many ways at all times, including (perhaps) through a strategically greater incorporation of imperialist or vanguardist techniques into a model that remains fundamentally and organically democratic. In this spirit of open exchange and egalitarian coalition, we invite all justice-minded scholars to join us in this never-finished effort; we invite all justiceminded scholars to join us in developing boundary-breaking coalitions; we invite all justice-minded scholars to join us in the continual development of this democratic approach to theory and action-the critical approach and collective location we think most likely to apprehend and create the intellectual, personal, and structural conditions necessary for enduring antisubordination transformation in and beyond the United States despite the limitations and shortcomings of the past dozen years. 


\section{APPENDIX}

Comparison of three models Matrix A: Conceptual Dimensions

\begin{tabular}{|c|c|c|c|}
\hline & \multicolumn{3}{|c|}{ Emphasizing Differences } \\
\hline & & \multicolumn{2}{|c|}{ Emphasizing similarities } \\
\hline $\begin{array}{l}\text { Relations of } \\
\text { production }\end{array}$ & $-\begin{array}{c}\text { Imperial / } \\
\text { traditional } \\
\text { (atomized) }\end{array}$ & $\begin{array}{l}\text { Vanguardist / } \\
\text { safe space } \\
\text { (small cells) }\end{array}$ & $\begin{array}{l}\text { Democratic / } \\
\text { big tent } \\
\text { (open zones) }\end{array}$ \\
\hline $\begin{array}{l}\text { Conceptual } \\
\text { Dimensions } \\
\end{array}$ & & & \\
\hline $\begin{array}{l}\text { Political econ- } \\
\text { omy / tenure } \\
\text { system }\end{array}$ & $\begin{array}{l}\text { Standards \& } \\
\text { style for produc- } \\
\text { tion set by tradi- } \\
\text { tional academy } \\
\text { tailored to for- } \\
\text { mal tenure proc- } \\
\text { ess }\end{array}$ & $\begin{array}{l}\text { Establishment of } \\
\text { annual work- } \\
\text { shops and } \\
\text { camps, or similar } \\
\text { small-scale gath- } \\
\text { erings by invita- } \\
\text { tion }\end{array}$ & $\begin{array}{l}\text { Community- } \\
\text { building through } \\
\text { knowledge- } \\
\text { production and } \\
\text { autonomous insti- } \\
\text { tution building }\end{array}$ \\
\hline $\begin{array}{l}\text { Mode of produc- } \\
\text { tion }\end{array}$ & $\begin{array}{l}\text { Individual } \\
\text { scholar embed- } \\
\text { ded in "home" } \\
\text { faculty or insti- } \\
\text { tution }\end{array}$ & $\begin{array}{l}\text { Small groups of } \\
\text { like-minded } \\
\text { scholars } \\
\text { w/common read- } \\
\text { ing lists }\end{array}$ & $\begin{array}{l}\text { LSA; SALT \& } \\
\text { LatCrit, Inc's } \\
\text { portfolio of pro- } \\
\text { jects and related } \\
\text { events. Reading } \\
\text { lists diversified by } \\
\text { discipline, for- } \\
\text { mats, identities, } \\
\text { language, and } \\
\text { nationality }\end{array}$ \\
\hline
\end{tabular}




\begin{tabular}{|c|c|c|c|}
\hline $\begin{array}{l}\text { Relationship } \\
\text { with social } \\
\text { change }\end{array}$ & $\begin{array}{l}\text { Incremental } \\
\text { reform through } \\
\text { appellate and } \\
\text { policy action }\end{array}$ & $\begin{array}{l}\text { Social justice } \\
\text { through critical } \\
\text { legal scholarship } \\
\text { and conscious- } \\
\text { ness }\end{array}$ & $\begin{array}{l}\text { Personal and col- } \\
\text { lective praxis ori- } \\
\text { entation to schol- } \\
\text { arship Global and } \\
\text { local locations }\end{array}$ \\
\hline $\begin{array}{l}\text { Site of produc- } \\
\text { tion of knowl- } \\
\text { edge }\end{array}$ & $\begin{array}{l}\text { Isolated individ- } \\
\text { ual } \\
\text { In the academy }\end{array}$ & $\begin{array}{l}\text { Cell or selected } \\
\text { small group } \\
\text { In safe-space } \\
\text { workshops }\end{array}$ & $\begin{array}{l}\text { An inclusive col- } \\
\text { lective } \\
\text { (diverse- } \\
\text { interdisciplinary } \\
\text { and activist); stu- } \\
\text { dents and local } \\
\text { communities } \\
\text { brought into dia- } \\
\text { logue }\end{array}$ \\
\hline $\begin{array}{l}\text { Why produce } \\
\text { knowledge? }\end{array}$ & $\begin{array}{l}\text { Influence judi- } \\
\text { cial action to } \\
\text { increase logical } \\
\text { coherence of } \\
\text { doctrine and } \\
\text { advance formal } \\
\text { policy goals }\end{array}$ & $\begin{array}{l}\text { Change prem- } \\
\text { ises and con- } \\
\text { tours of socio- } \\
\text { legal discourse } \\
\text { and legal action. } \\
\text { Self-critical } \\
\text { about power- } \\
\text { knowledge and } \\
\text { privilege }\end{array}$ & $\begin{array}{l}\text { Create emphasis } \\
\text { on performative } \\
\text { aspects of aca- } \\
\text { demic work, build } \\
\text { community \& } \\
\text { motivate social } \\
\text { change. Self- } \\
\text { critical about } \\
\text { power-knowledge } \\
\text { and privilege }\end{array}$ \\
\hline $\begin{array}{l}\text { Gaze of power- } \\
\text { the asymmetry } \\
\text { of "looking" at } \\
\text { those with less } \\
\text { power \& privi- } \\
\text { lege }\end{array}$ & $\begin{array}{l}\text { Imperial ex- } \\
\text { change through } \\
\text { citational prac- } \\
\text { tices and star } \\
\text { systems }\end{array}$ & $\begin{array}{l}\text { Intensive small- } \\
\text { group encoun- } \\
\text { ters at annual } \\
\text { camps, work- } \\
\text { shops, etc }\end{array}$ & $\begin{array}{cl}\text { Corrections } \\
- & \text { Self- } \\
& \text { critique } \\
- & \text { Shifting } \\
& \text { bottoms } \\
- & \text { conscien- } \\
& \text { tización }\end{array}$ \\
\hline
\end{tabular}




\begin{tabular}{|c|c|c|c|}
\hline $\begin{array}{l}\text { Recruitment and } \\
\text { reproduction of } \\
\text { newer scholars }\end{array}$ & $\begin{array}{l}\text { Formal process } \\
\text { of hiring, pro- } \\
\text { motion and ten- } \\
\text { ure, both at en- } \\
\text { try and lateral } \\
\text { levels. } \\
\text { "Society of } \\
\text { One" }\end{array}$ & $\begin{array}{l}\text { Invitation of } \\
\text { seemingly like- } \\
\text { minded to small } \\
\text { annual events. } \\
\text { "A Few Good } \\
\text { Wo/Men" }\end{array}$ & $\begin{array}{l}\text { Broad outreach } \\
\text { and inclusion } \\
\text { through events, } \\
\text { projects, texts and } \\
\text { related informa- } \\
\text { tional resources. } \\
\text { In/formal mentor- } \\
\text { ing } \\
\text { "Critical Mass" }\end{array}$ \\
\hline $\begin{array}{ll}\text { Connection } & \text { of } \\
\text { scholarship } & \text { to } \\
\text { teaching role } & \end{array}$ & $\begin{array}{l}\text { Formally an } \\
\text { aspiration, but } \\
\text { not central or } \\
\text { necessary }\end{array}$ & $\begin{array}{l}\text { A general aspi- } \\
\text { ration but ap- } \\
\text { plied most } \\
\text { commonly in } \\
\text { identity/equality } \\
\text { seminars }\end{array}$ & $\begin{array}{l}\text { Integrated as fully } \\
\text { as possible across } \\
\text { courses. Alliances } \\
\text { with progressive } \\
\text { students. Aspira- } \\
\text { tion is to remake } \\
\text { the academy }\end{array}$ \\
\hline $\begin{array}{l}\text { Intellectual ten- } \\
\text { ets }\end{array}$ & $\begin{array}{l}\text { Individualism; } \\
\text { Incrementalism; } \\
\text { Objectivity; } \\
\text { Neutrality; Bal- } \\
\text { ancing of inter- } \\
\text { ests }\end{array}$ & $\begin{array}{l}\text { Structuralism; } \\
\text { Transformation; } \\
\text { Subjectivity; } \\
\text { Political; } \\
\text { Favors "the bot- } \\
\text { tom" }\end{array}$ & $\begin{array}{l}\text { Antisubordination } \\
\text { in multidimen- } \\
\text { sional and activist } \\
\text { terms }\end{array}$ \\
\hline $\begin{array}{l}\text { Substantive } \\
\text { Aims }\end{array}$ & $\begin{array}{l}\text { Doctrinal coher- } \\
\text { ence and legal } \\
\text { reform }\end{array}$ & $\begin{array}{l}\text { Material and } \\
\text { cultural trans- } \\
\text { formation of } \\
\text { society and legal } \\
\text { culture }\end{array}$ & $\begin{array}{l}\text { Material and cul- } \\
\text { tural transforma- } \\
\text { tion of society and } \\
\text { legal culture } \\
\text { based on expan- } \\
\text { sive commitments } \\
\text { to multidimen- } \\
\text { sional antisubor- } \\
\text { dination activism } \\
\text { as core academic } \\
\text { work }\end{array}$ \\
\hline
\end{tabular}


Comparison of three models Matrix B: Operational Dimensions

\begin{tabular}{|c|c|c|c|}
\hline & \multicolumn{3}{|c|}{ Emphasizing Differences } \\
\hline \multirow{2}{*}{$\begin{array}{l}\text { Relations of } \\
\text { production }\end{array}$} & & \multicolumn{2}{|c|}{ Emphasizing Similarities } \\
\hline & Imperial / & $\begin{array}{l}\text { Vanguardist / } \\
\text { safe space }\end{array}$ & $\begin{array}{l}\text { Democratic / } \\
\text { big tent }\end{array}$ \\
\hline $\begin{array}{l}\text { Operational } \\
\text { Dimensions }\end{array}$ & & & \\
\hline $\begin{array}{l}\text { Organizational } \\
\text { Aims }\end{array}$ & $\begin{array}{l}\text { Maintenance of } \\
\text { legal academy } \\
\text { and Law as key } \\
\text { social institution }\end{array}$ & $\begin{array}{l}\text { Creation of sub- } \\
\text { versive texts that } \\
\text { help to catalyze } \\
\text { transformative } \\
\text { social change }\end{array}$ & $\begin{array}{l}\text { Creation of self- } \\
\text { sustaining networks } \\
\text { of critical scholars } \\
\text { and activists } \\
\text { working for social } \\
\text { transformation in } \\
\text { various ways re- } \\
\text { lated to knowl- } \\
\text { edge-production }\end{array}$ \\
\hline Audiences & $\begin{array}{l}\text { Appellate judges } \\
\text { primarily }\end{array}$ & $\begin{array}{c}\text { Mainstream actors } \\
\text { generally }\end{array}$ & $\begin{array}{l}\text { Outsider commu- } \\
\text { nities }\end{array}$ \\
\hline $\begin{array}{l}\text { Identity } \\
\text { demographics }\end{array}$ & Heteropatriarchal & Of color & Eclectic \\
\hline Methods & $\begin{array}{l}\text { Traditional texts } \\
\text { and presentations }\end{array}$ & $\begin{array}{l}\text { Subversive texts } \\
\text { and storytelling }\end{array}$ & $\begin{array}{l}\text { Subversive texts } \\
\text { and per- } \\
\text { sonal/collective } \\
\text { praxis }\end{array}$ \\
\hline $\begin{array}{l}\text { Types of } \\
\text { scholarship }\end{array}$ & Doctrinal mostly & Theoretical mostly & $\begin{array}{l}\text { Eclectic/Counter- } \\
\text { disciplinary }\end{array}$ \\
\hline
\end{tabular}




\begin{tabular}{|l|l|l|l|}
\hline $\begin{array}{l}\text { Subject } \\
\text { position/ } \\
\text { Stance }\end{array}$ & $\begin{array}{l}\text { Mainstream } \\
\text { (more or less } \\
\text { liberal) }\end{array}$ & $\begin{array}{l}\text { Outsider/Critical } \\
\text { Counterhegemonic } \\
\text { stance }\end{array}$ & $\begin{array}{l}\text { Outsider/Critical } \\
\text { Multidimensional, } \\
\text { antisubordination } \\
\text { stance }\end{array}$ \\
\hline $\begin{array}{l}\text { Institutional } \\
\text { Frameworks }\end{array}$ & $\begin{array}{l}\text { Core institutions } \\
\text { of legal academy }\end{array}$ & $\begin{array}{l}\text { Annual small/ } \\
\text { closed event }\end{array}$ & $\begin{array}{l}\text { Portfolio of vari- } \\
\text { ous projects open } \\
\text { to all, both local } \\
\text { and international }\end{array}$ \\
\hline
\end{tabular}

